\title{
Progress of Building Materials and Foundation Engineering in Ancient Iraq
}

\author{
Entidhar Al-Taie, Nadhir Al- Ansari, Sven Knutsson \\ Department of Civil, Environment and Natural Resources Engineering, Lulea University of \\ Technology,97187 Lulea, Sweden.
}

Entidhar.altaie@ltu.se, Nadhir.ALAnsari@ltu.se, Sven.Knutsson@ltu.se

\section{Keywords:}

Assyrian, Babylonian, Mesopotamia, liben, mud, bricks, ziggurat, stones, built, temples, plan, mortar, tar.

\begin{abstract}
Humans realised the importance of housing since the dawn of history. The first man used the caves as shelter. When agricultural activities dominated the life style of humans, villages started to be constructed. Later these were developed into cities.

The dawn of civilization started in Iraq. The inhabitants in that time used the available natural materials in their construction. Reviewing the progress of engineering practices of ancient Iraq, reveals the facts that the inhabitants were aware of the principles of construction and engineering. The materials used and the design of the buildings were very suitable from both environmental and engineering perspectives.

This work is a critical review of the progress and development of engineering practices and construction materials used in ancient Mesopotamia

\section{Introduction:}

Buildings reflect the culture, environment and economy of the society. Humans recognized the importance of buildings before the dawn of civilization. In the beginning of human life, people were using caves and stones to build their homes in mountainous areas; in plan areas they used clay while in the marshes they used reeds and papyrus. All these were isolated housing units. The situation changed when humans used agricultural activities to survive. At this stage of agriculture and domestication of animals they were in need for larger houses to accommodate the expansion needs of animals and storage of surplus from agriculture. Then they required temples so that the "gods" guard them and their property. Agricultural activities require community work and that developed the signs of small villages which were later developed to cities. At this stage the buildings took new forms as well as the construction materials. The cities increased its development and diversified construction materials and components introduced in new form, such as marble stone and brick glazed with prominent images or sculptures [2].

Building systems depend on the unit construction, which consists of natural or artificial materials or their mixtures. Construction work means the use of units bounded by the material used and the distribution of weights should be homogenous. The prevailing methodology was that the weight are moved starting from the ceiling to the columns and foundations and then to the soil. [3].

The unique specification of Iraq (presence of plan areas and Tigris and Euphrates Rivers) encouraged the humans to use this land. The civilization started in Iraq 7000 years ago. At that time human history marked the rise the art of architecture and construction in Mesopotamia, and the world was witness to the construction activities in Iraqi for hundreds of years ago The most important factors that helped the creativity and activity was the beliefs religious peoples that inhabited in Mesopotamia, have to serve their Gods by building temples of luxury and decent. From here it is clear that the prosperity of architecture and growth began in the temples and the back of excellence in it. The most important building found in cities buried is the temples, which contained either the tower or ziggurat topped with a house of the greatest God of the city.
\end{abstract}


The Semites and the Sumerians developed the cornerstone of human civilization, the first (dating back to 3500BC) through the revival of land for agriculture and housing. Settlement began in the southern part of Mesopotamia through the construction of huts in small villages in the high places and far from the river to avoid flooding. These later developed to cities. People in these cities were interested in the construction of dams to be protected them from external aggression and also from the flood. From this perspective, walled cities like the city of Kish, Uruk (Warka) were built. Temples of mud brick decorated with metal and stone works, and invented the cuneiform writing, as well as maps and measuring instruments shown by the statue of king Codaa ruler of Kish.

After this successive civilizations dominated Iraq. The remains of the buildings are distributed all over Iraq (Figure1.1). The buildings and construction materials used during that period of time will be reviewed and discussed.

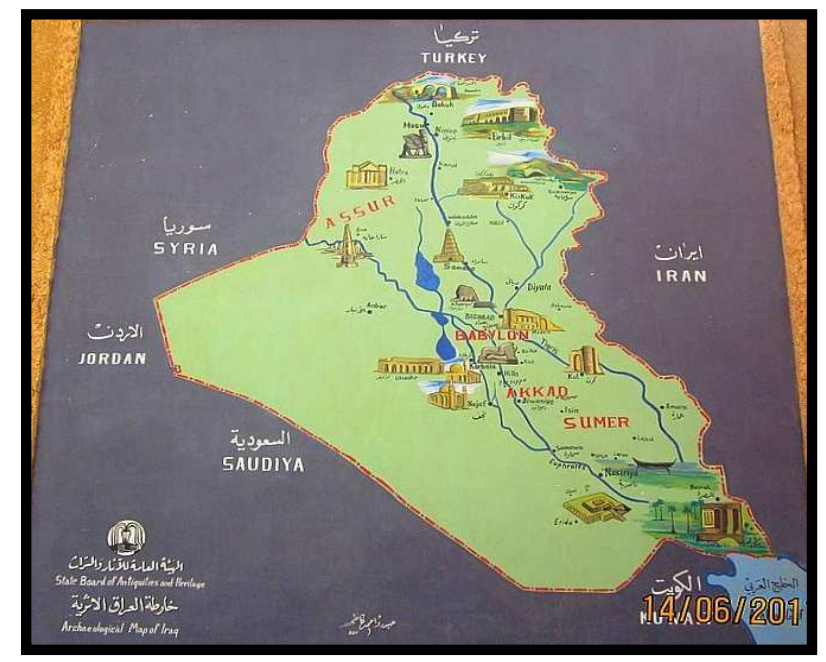

Fig. 1.1: Archaeological Map of Iraq [5]

\section{The Old Population of Iraq (Stone ages, 150,000BC to 8000BC)}

In Mesopotamia the oldest civilizations were discovered. They were:

2.1 Old Stone Age (Palaeolithic) (150,000 BC to 12000 BC): About 100,000 year ago, people lived in caves in northern Iraq and used its stones for the manufacture of their instruments. The oldest caves are Zouza cave, Hazairmrd cave in Sulymaniyah city. The dimensions of one of the well known caves "Shanider" in Rawanduz Mountains, $25 \mathrm{~m}$ for the width, $8 \mathrm{~m}$ for high of the entrance to the cave, $40 \mathrm{~m}$ long and $53 \mathrm{~m}$ wide from inside[6] (Figure 2-1).

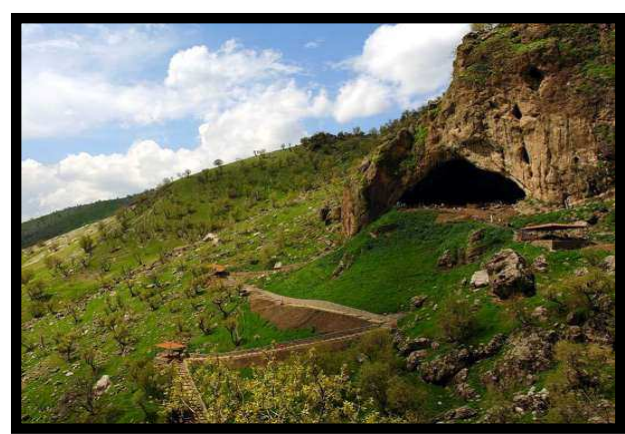

\section{A. Outside view of Shanider Cave}

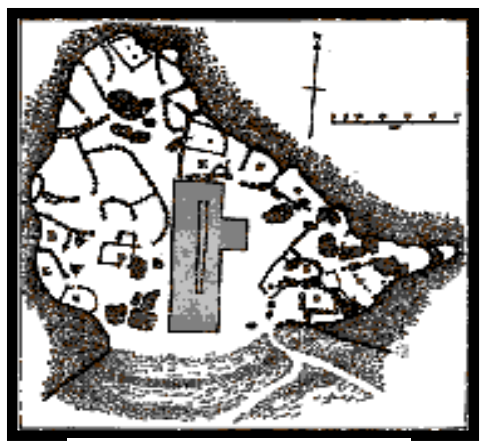

B.Cave plan

Fig. 2-1: Shanider Cave [7] 
2.2 Median Stone Age (Mesolata) (12000 BC to 8000 BC): About 10000 years BC: The inhabitants move to plains near the caves and began to settle and cultivate the land. Zawe Jamie settlement was one of the oldest discovered and located on the banks of the Zab River to the west of the Shanider cave (Figure 2.2). The foundations of the houses built by the people of the settlement were of mud. The houses were circular in shape having a diameter of about $4 \mathrm{~m}$. The thickness of the walls was $1.65 \mathrm{~m}$, and the foundation was made of natural large stone [8].
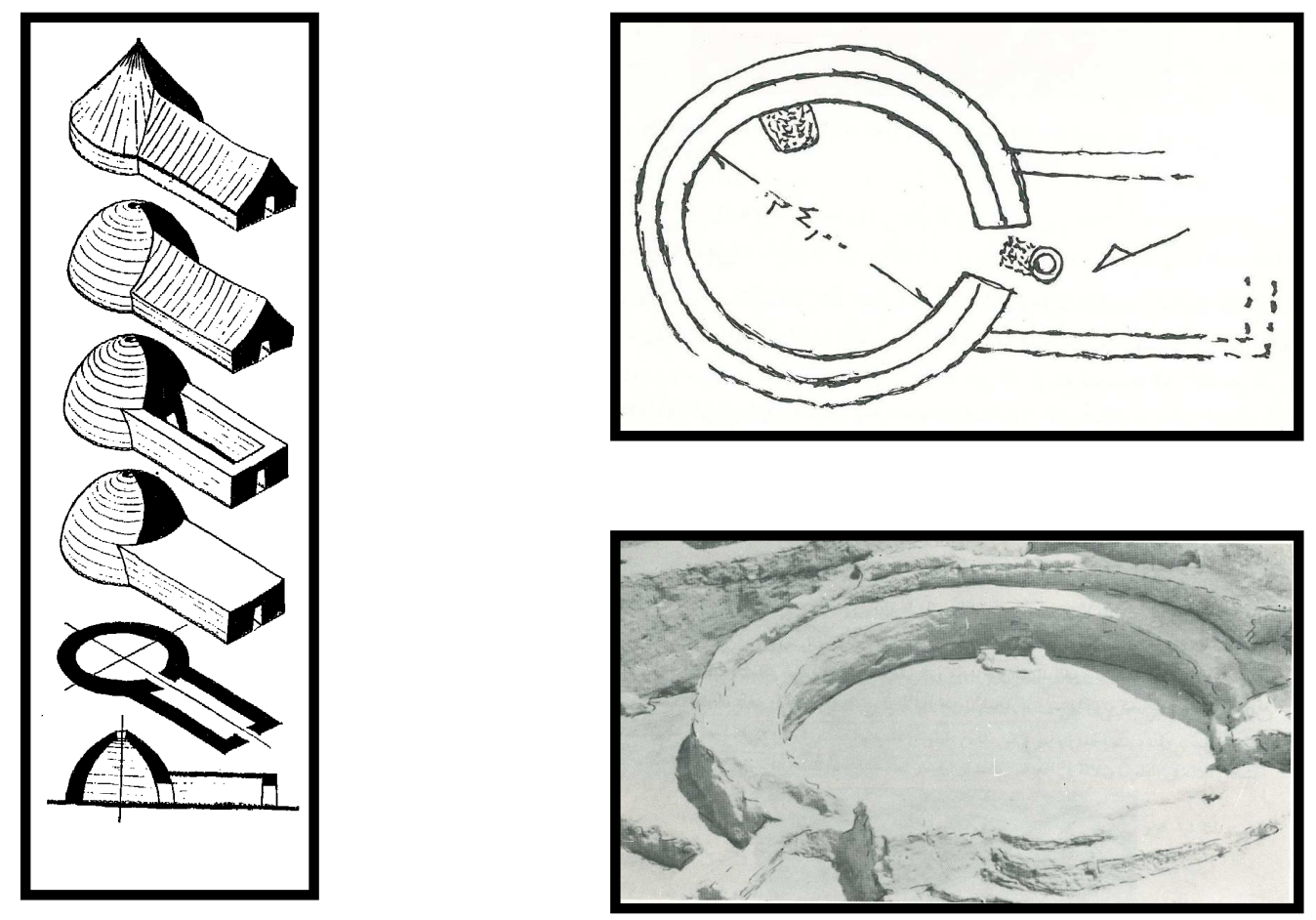

Fig. 2.2: The Round House and its Plan $[1,8]$

2.3 The Neolithic Age (8000 BC to 5000 BC) :The relics and remains of villages discovered in Iraq belonging to this age reflected the development that took place in people's life. At this stage the people left the caves and started to live in villages. Garmo village that dates back to $6700 \mathrm{BC}$ is an example in the northern part of Iraq. In this village a new style of buildings appeared. The houses were rectangular in shape and contain more than one room. The materials used for building were mainly mud. They also used stones in the foundation. Columns were used and the walls they were stuffed with strand of willow twigs. The floor was covered with mud and wood and reed were used in the ceiling.

In Joukh Mary village, which is located in north-western of Iraq, the basis of the tower was found at the entrance of the village which is built of material liben (mixture of clay and at the remains of barley). The foundations of the house in the village were rectangular in shape. The houses contains number of rooms, the walls were build with liben long-like Cigar of long size. These were arranged as bands of three vertical columns and three horizontal columns (EIIIEIII). [1][4].

2.4- Pre- Strains Age (6000 BC to 3000 BC): This period extends from 6000 to $3000 \mathrm{BC}$, it include Stone Age Metal and characterized by unique type of buildings. Some of the buildings were circular in shape with diameter ranging between 5 to $7.5 \mathrm{~m}$ in the form of bees cells (Figure 2.3). The foundation material were stones while the walls were built by mud, the roofs were pinned in the domes. Other types of houses were also found. Their diameter was about $18 \mathrm{~m}$ and the thickness of the walls was $1 \mathrm{~m}$. 


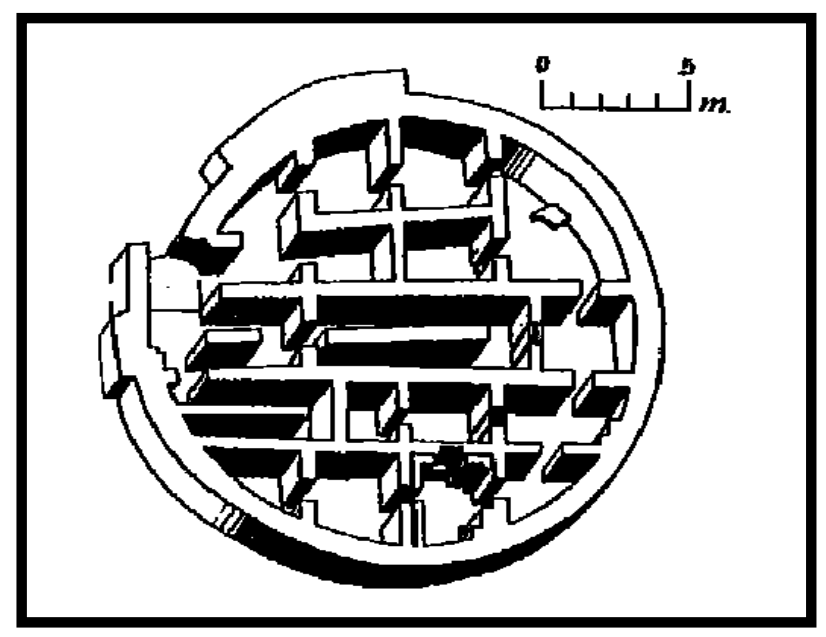

Fig. 2.3: Around house in Taba Gawr [8].

Another site is the Tel Halif located on the river Alkabour. This site represents the development of farming villages in the methods of organization and construction of buildings. Streets paved with natural stones were noticed and clay was the basic materials for construction.

The early inhabitant in the south of Iraq lived in huts of reeds and then they developed their building and used bricks made of mixture of mud and barely (liben) which is not grilled and it was used for building houses and temples.

At Jamdat Naser site, the foundations of large building, believed to be a palace, was found. Houses were constructed from raft (clay mixed with straw). Villages became cities. They used liben having convex- straight shape. The buildings were built with foundation under the ground surface, where earlier, buildings where built on the surface of the ground directly. Temples were separated from other buildings [4][8].

At Warka age (following Al Obedian Age ) buildings (houses, some built with canes and papyrus, clay, and some are built from bricks) were found in Eridu. High temples were also found. They were constructed of stucco and stones. They had massive walls supported by substrates from inside and sometimes from outside. They were decorated with cones of grilled mud and some of the collared stones (black, white and green). In Eridu, multiple layers of temples were discovered, which ended with ziggurat's temple (III). This was built with small size bricks $(21 * 12 * 7 \mathrm{~cm})$ of reddish clay, while temple(IV) was built with medium size bricks $(29 * 12 * 8,26 * 13 * 7 \mathrm{~cm})$ of greenish clay, and temple $(\mathrm{V})$ was built with large bricks $(42 * 20 * 8,41 * 22 * 8 \mathrm{~cm})$ of light- coloured clay with dark joints( Figure 2.4). 


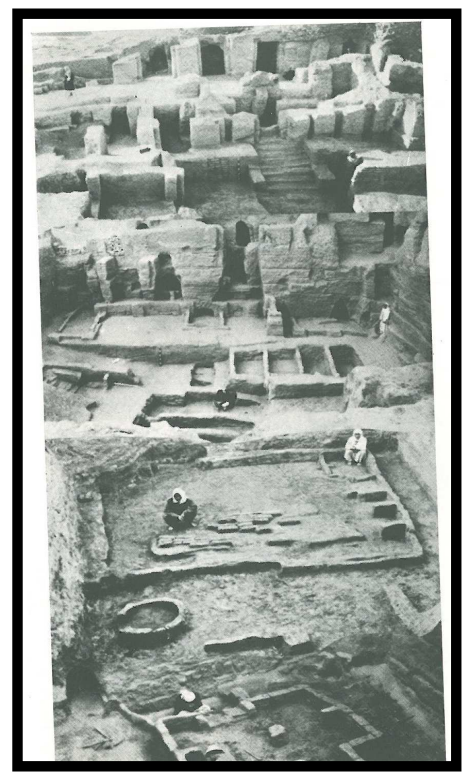

Fig. 2.4: Multiple layers of Eridu temple [9].

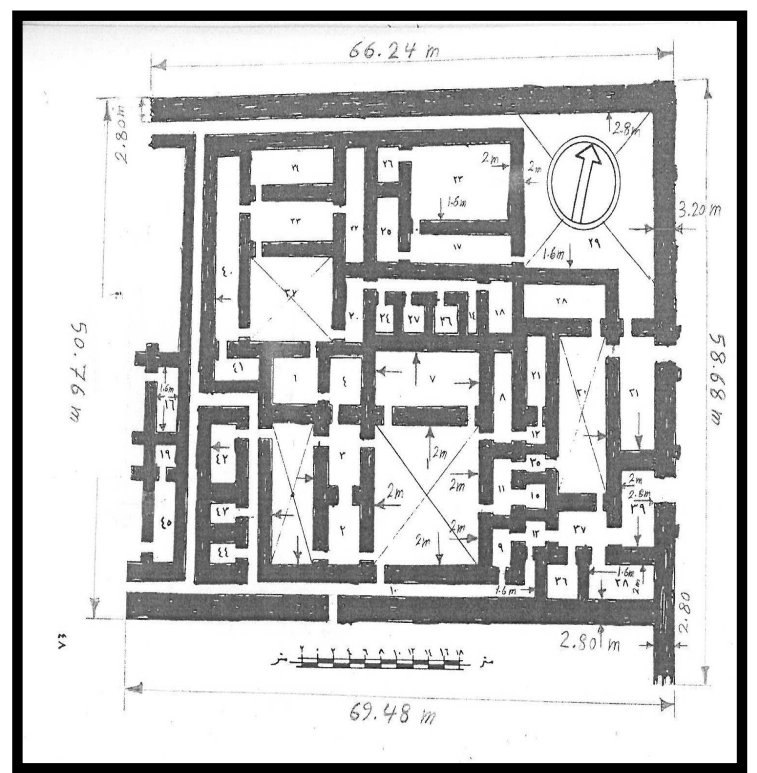

Fig. 2.5: Plan of north [1]

Two similar palaces were also built in Eridu. One of them is the north palace( Figure 2.5), which was built in rectangular shape. Its width is $45 \mathrm{~m}$ and the length is $68 \mathrm{~m}$. The walls were $2.60 \mathrm{~m}$ thick. They were built with bricks (convex- straight type). The outer walls, which represent the wall that protects the building, had thicknesses range of 2.80 to $3.20 \mathrm{~m}$. This also represents the thickness of the foundations of the building. The internal walls had thickness range of 1.60 to $2 \mathrm{~m}$. The palace has two thick walls outside, with narrow corridor to protect the palace from moving.

New style of building was also noticed in Eridu. These are temples built on artificial hill, which can be climbed by side slopes upward. The people learned to use adobe industry. They used bricks made of liben of mud (scale $49 * 26 * 8 \mathrm{~cm}$ ), which were used to built houses and cover them with mud [1].

In Tel Al Aquer, located 50 miles south of Baghdad, walls about $2 \mathrm{~m}$ thick coated with layer of mud 3 to $5 \mathrm{~cm}$ thick were found as parts of what is known as colored temple. These walls were decorated from the outside with wavy interventions made of white plaster; with one block of solid cemented liben as the terrace built up to height of $5 \mathrm{~m}$.It was built in two stages set up on land which is furnished with mud. The shape of the terrace looks like the letter D (Figure 2.6). Adorn the walls of the terrace, successive interventions representing the pillars of consolidation, up 4,60m height. go They end in to a cornice with five lines of mosaic cones made of grill clay(flat from one side and painted from the other side) with diameter of $8 \mathrm{~cm}$, and $20 \mathrm{~cm}$ long(Figure 2.7).

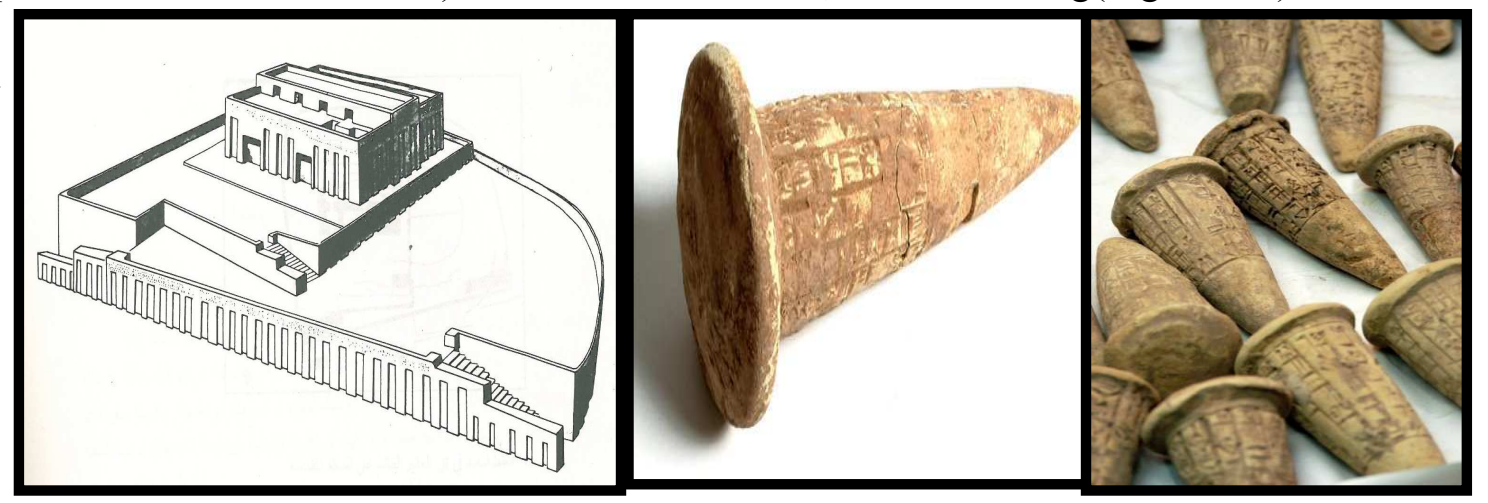

Fig.2.6: in Tel AL Aqure [1]

Fig.2.7: The Colored Mosaic

of cones Temple [34] 
There is also a stairway up to the bench in the lower ends of the north-eastern side which is bordered by a third-party socket and the inside a small channel to drain rain water. The highest terrace is coated with a layer of asphalt on which they built the walls of the temple.[1][6][9]

The pattern of construction was more developed where they started to use pottery and twisted nails to decorate the buildings. High temples (ziggurats) were also built. These building are important characteristics of Mesopotamia civilization.

In Warka a groups of arched complex buildings were built representing the largest urban Sumerian engineering work. They built a temple based on foundation (terrace) of the limestone, dimensions $75 * 29 \mathrm{~m}$, and it was decorated with cones mosaic made of red, black and white pottery (length10$15 \mathrm{~cm}$ ), mounted on the wall covered by a layer of clay. The temple was referred to as the limestone temple (Figure2.8).

In this period the buildings were characterized by use of a rectangular box of liben with square sections. Square plates of limestone were found for the first time in these building. These plates had a hole carved in the centre. No body knows the exact use of these plates and it was suggested that they might be bases for flags or foundation stones or paintings (Figure 2.9). They also used liben (convex-straight type), which was put in zigzag rows (Figure2.10. Most of the buildings had underground foundations. This stage represents the end of the pre-historical period and the bases of Iraq's civilization [4].

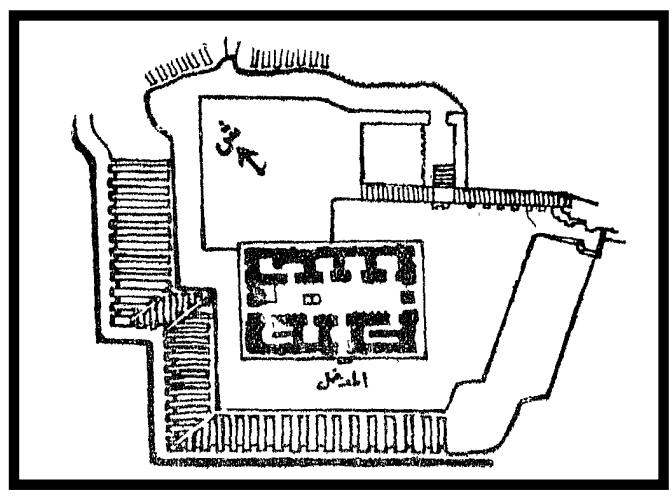

Fig. 2.8: The Limestone [10] Temple.

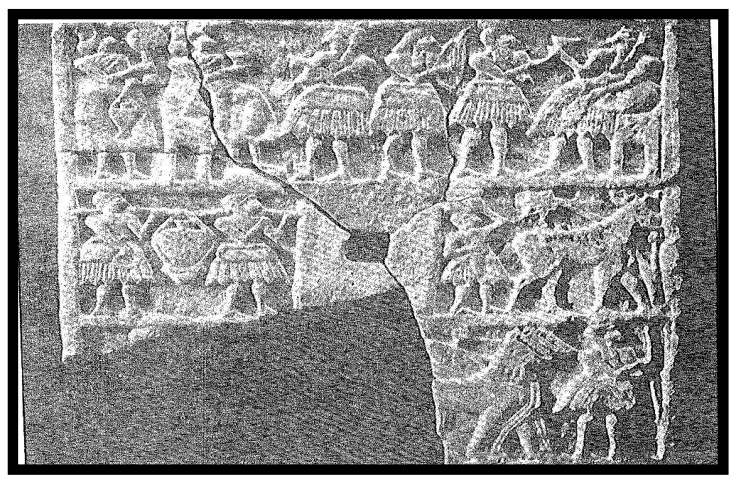

Fig. 2.9: Limestone [1] plates.
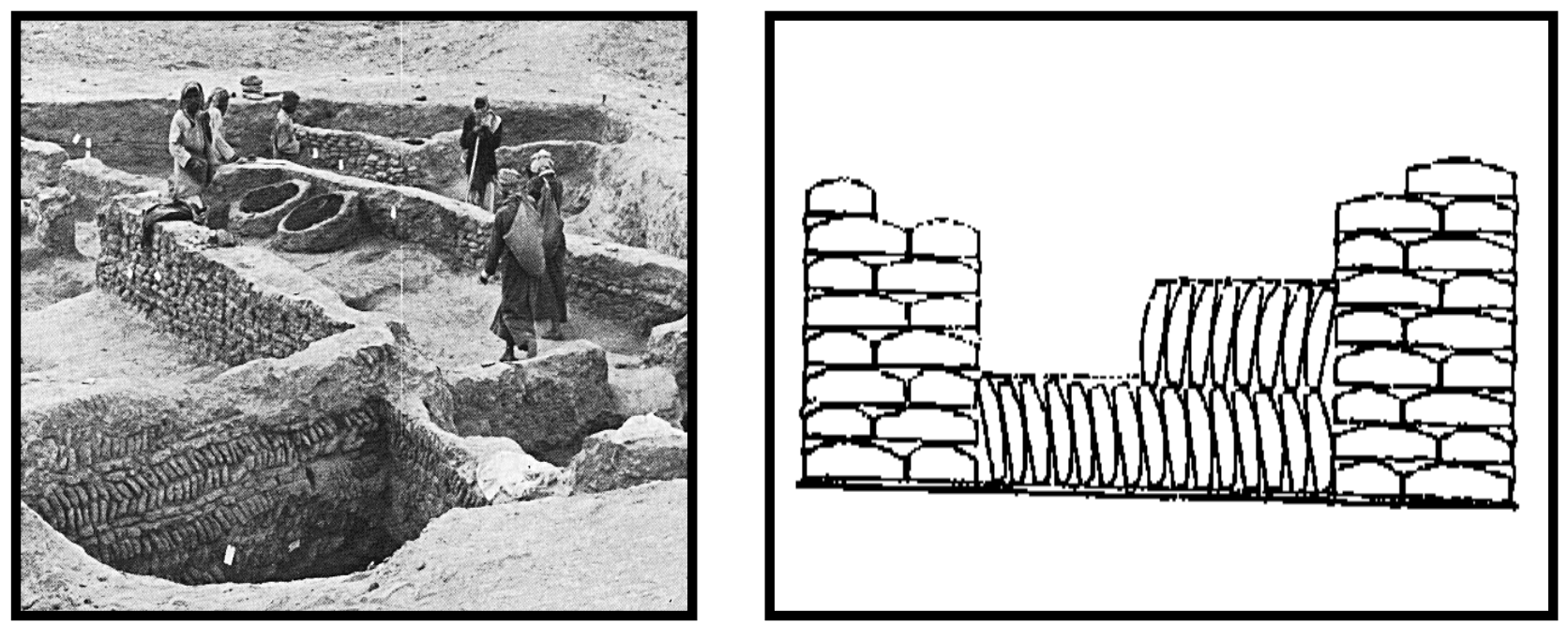

Fig. 2.10: Liben (convex-straight type)/8 used//8 in [8] rows. 


\subsection{Beginning of the Era of Dynasty (3000 BC to 2370 BC) :}

The construction of buildings and temples in this era continued to be maintaining the same structure and materials used before. It should be mentioned however that the size and heights of the buildings were much larger. The dominant building material was liben (convex-straight type).

\section{Historical Time in Mesopotamia (2370 BC to 539 BC):}

3.1- Akkadian Empire (2370 BC to 2159 BC): Engineering work in this era was characterized by the use of liben $($ size $52 * 52 \mathrm{~cm}$ ) having square cross section. Palaces were more important than temples in this stage.

King Naram Sin built two palaces at Tel Bark; one of them is a fort and hostel for travellers. It consist of 4 courts (one large and three smaller), number of rooms and halls. Square wall (thickness $10 \mathrm{~m})$ was surrounding the palace. The second palace was built in square shape $(100 * 100 \mathrm{~m})$. The walls were thick and it contains many cellars (Figure 3.1).
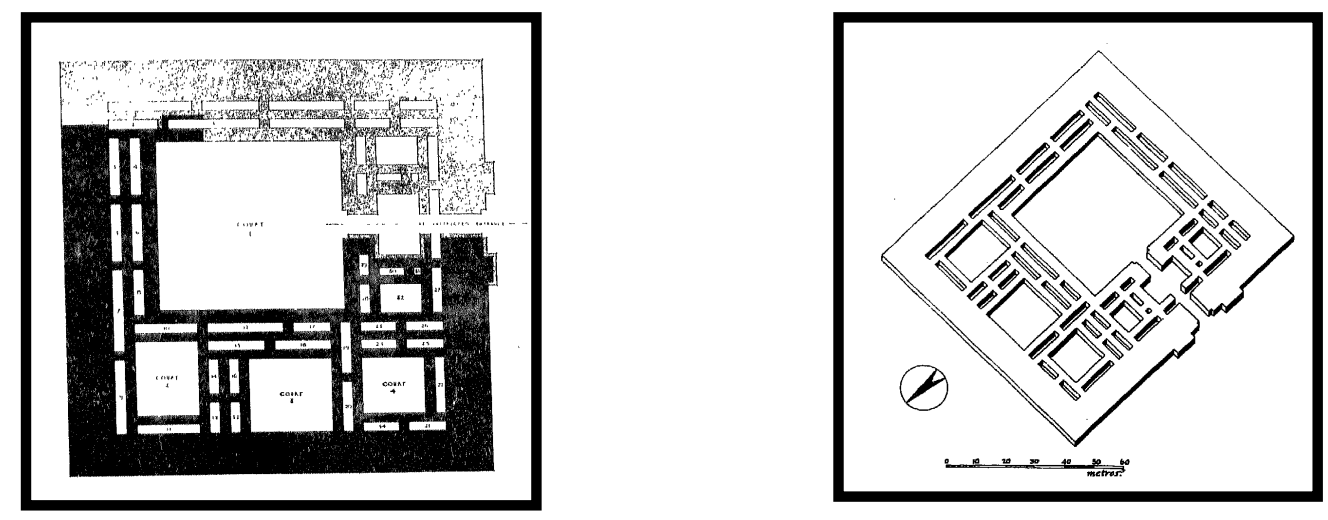

\section{Fig. 3.1: The foundations plan of palace and fort Akkadian king} Naram Sin in Tell Brak. $[8,11]$

\subsection{The Third Dynasty of Ur (2111 BC to 2003 BC):}

Temples built by king Ur-Nammu (2111-2094BC) are the main features of engineering work in this era. He invented the idea of building high ziggurat. The building was located in such away that they were parallel to the geographic directions. The builders were aware of the importance of wind and sun rise and sun set directions. The king made huge projects, among which is surrounding the city Ur with great wall $(27 \mathrm{~m}$ thick) made of mud. The aerial view of the city looks oval in shape. Prallal to the city wall a barricade of brick clay was constructed. The upper part of the barricade had slope. One of the king's achievements was the high and big ziggurats, which were solid building by liben coated with bricks from the out side, consisted of several layers topped with small temple called the top temple with another temple at the bottom. All the building was surrounded by a big wall containing many rooms [14].

The famous ziggurat of Ur-is red in colour due to the use of grill wage. It was constructed in three layers and on the top layer the temple was built. The structure was built from thee outside with either grilled wrapped bricks (brick red) with thickness of $2.4 \mathrm{~m}$ between the mortar tars compatible with canes woven in thick layers, the inside part was built with grill wage. Lower layer of ziggurat $(61 * 45.7 \mathrm{~m})$ was built in with high of about $15 \mathrm{~m}$ above the terrace of liben. The dimensions of second layer is $36^{*} 26 \mathrm{~m}$ with high of $5.70 \mathrm{~m}$, the third layer is $20^{*} 11 \mathrm{~m}$ with high of $3 \mathrm{~m}$, and the amount of slope to the interior ribs are about $11.70 \mathrm{~cm}$ per meter[10].

It has three stairs, one in the middle, $28 \mathrm{~m}$ long with 93 steps and its width about 2.70 to $3 \mathrm{~m}$, with high of $12 \mathrm{~m}$. The other two are on the sides of the building with high of $12 \mathrm{~m}$, length of $29.50 \mathrm{~m}$, with 100 stairs each. Each ladder rack with 82 steps, depth and the high per step is the same as of the stairs, and the two stairs join to the central and continues to climb to the second layer [1]. One of the unique characteristics of the structure is that the walls look concave although they are vertical (Figure 3.2). Fire was used to dry the bricks used inside. Holes penetrating the outer casing were made possibly to grow trees [12]. 
Another peculiar structure which was built by King Ur- Nammu is the royal cemetery. It was built under the ground with burial chambers and corridors. All these were covered by arches made of mud brick, and can be accessed through the ladder and its entrance triangle shape (Figure 3.3).

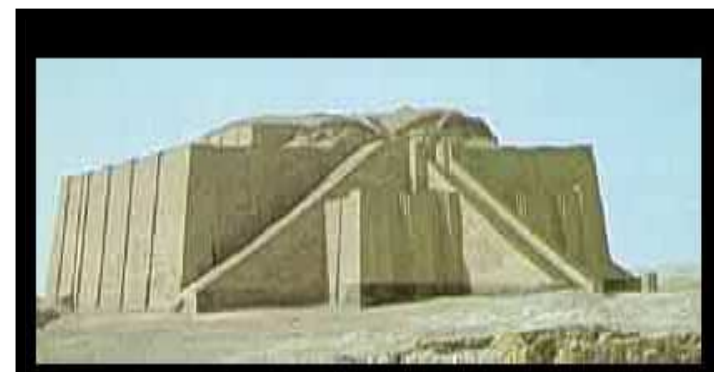

www, m3mare, com

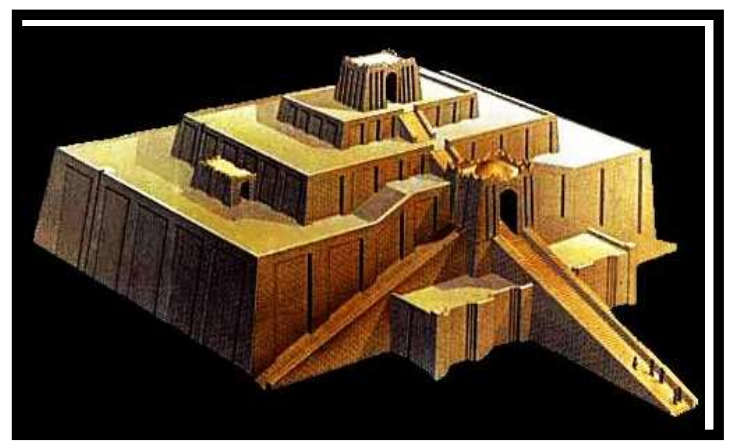

Figure 3.2: The Ur Ziggurat. [13]
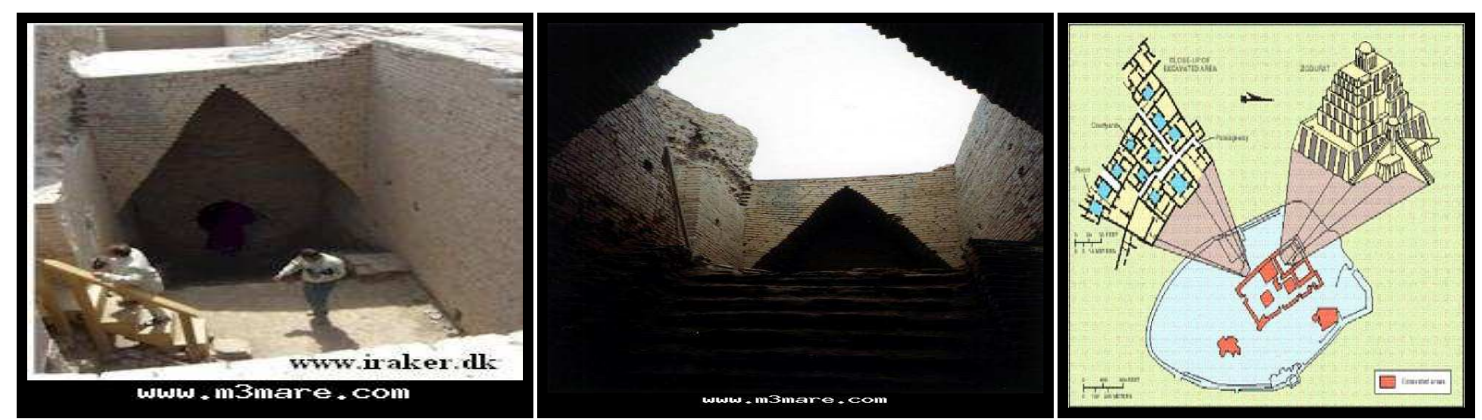

Fig. 3.3: The entrance to the royal cemetery of king Ur Nammu [13]

People's homes were built in the style apart from one house belonging to Prophet Abraham. This house had an internal library and some overlapping and adjacent rooms. They were separated by corridors of semi-circular arches and there are stairs between the rooms which indicate that the house was on different levels. Houses in the city of Ur were containing heavy water drainage systems, which is the first of its kind at the time. The technique used in the building the houses reflects the skill of creative engineers and architects. The building materials used were grill liben and the ground was covered with alvrchi (pieces of slabs of grilled clay with different measurements) (Figure3.4).
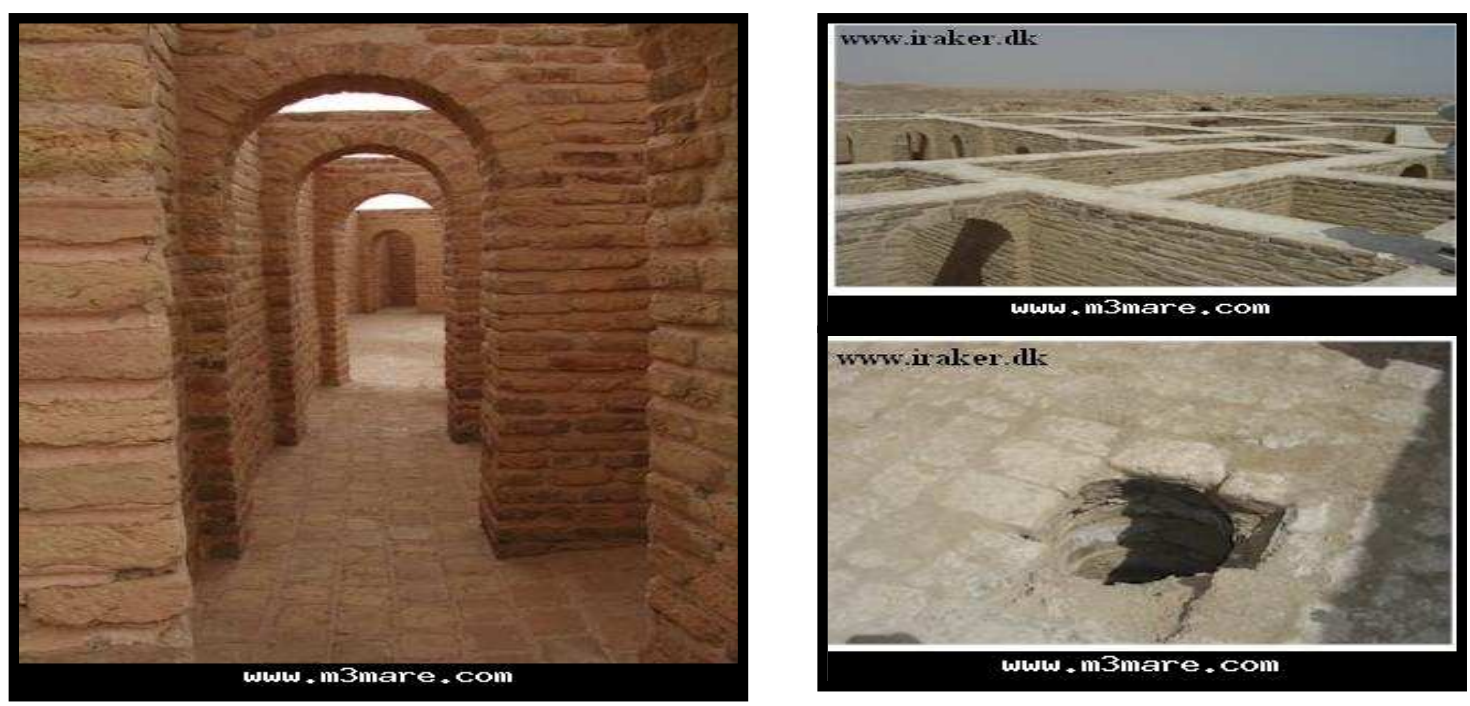

Fig. 3.4: House of the Prophet Ibrahim at Ur city [13]. 
Warka ziggurat was built in a different way, as encapsulated from the outside with a layer of compressed liben. Layers of mats made of reeds were put between the layers of mud at equal distances to increase the connectivity between the layers of liben. Belt of reed was used in the upper layers and ropes (about $70 \mathrm{~cm}$ thick) were laid in holes penetrating the heart of the building in horizontal channels assist the outer walls (Figure 3.5).
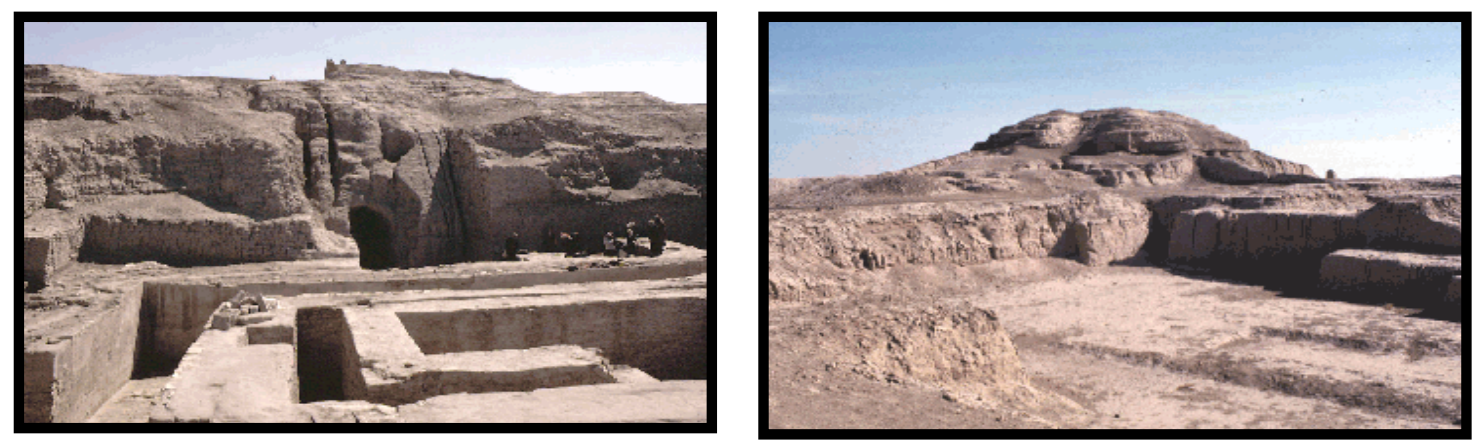

Fig. 3.5: Warka ziggurat and the temple beside it [15].

Temples have been built in all the eras with liben and it was noted that asphalt material was installed in the lower part some of the outer walls of the temples for supporting them. Statues (made of bronze or wood or stone) in the form of a nail were placed in the foundations in the four corners of the palaces and temples called the foundation statues. They are usually representing the king holding a bowl of construction (Figure 3.6). Some times these statues represent animals or humans and are called human or animal nails. Pillars and columns of sandstone were also found. They were of square shape $(50 * 50 \mathrm{~cm})$ and about $10 \mathrm{~cm}$ thick. These were laid in circular shape and coated by a layer of layer of lime mixed with fine gravel [17].

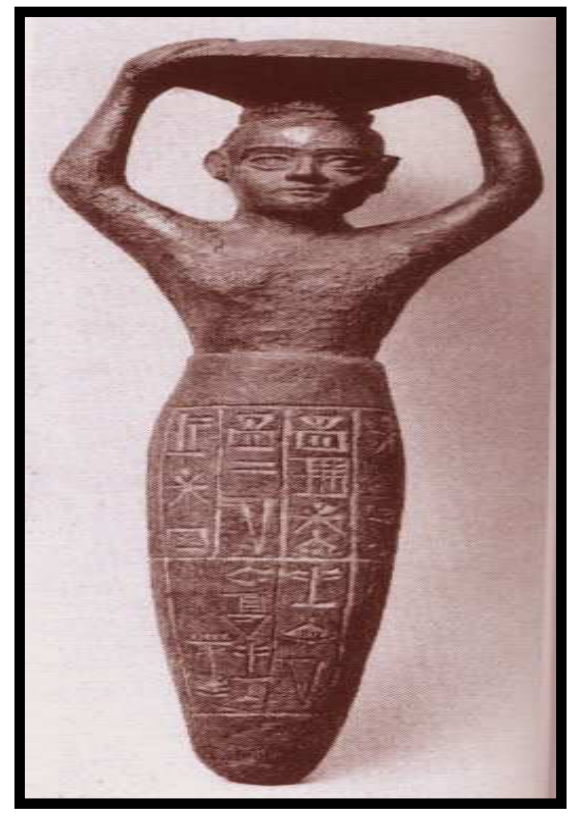

Fig. 3.6: The statue of Ur-Nammu used as nails in the foundation [16].

3.3 The Old Babylonian Era: (From 1894BC years to 1595BC years) This era is characterized by the building of huge splendour palaces in spite the fact that building temples also continued. The area of the palace was usually $200 * 140 \mathrm{~m}$. In the middle of the area there is a court and rooms are built around it. One of these rooms is the meeting room which is big and semi rounded with stairs. Beside this room is the king's throne room which is the biggest room in the palace. The construction material is limestone while for temples it was liben[1]. 
In the kingdom of Ashnona (same period but on Diyala River), temple of Abu was found on old based on several layers of the same structural temple, built with liben (level-straight type) and was square in shape with protector wall for the exterior walls(Figure 3.7). Another temple was built in Tel-Khafaji, oval in shape, was also built with liben (level-straight type)(Figure 3.8). Wage was use as a base for the walls and some times it consists of small bricks arranged in such away to form panel that might be 2 to $3 \mathrm{~m}$ high. These were used to decorate the walls (e.g. Ishtar Gate).

In this era they continued building ziggurats, which where either of the type containing stairs or the kind of slopes. They had a height of two layers to seven layers. The ziggurats built in this period characterized by their altitude and the method of construction which is distinctive (e.g. DorKurigalzu presently known as Aqarqouf). It reached a total height of $78 \mathrm{~m}$ with a area of its base reaching $78 * 78 \mathrm{~m}$. The hight of its first layer is $33 \mathrm{~m}$. The technique that they used was to build the tower with a square base and the height of the tower equals the side length of the base side length (Figure 3.9). Using the length of the lateral stairs $(50 \mathrm{~m})$ the height of the first layer was calculated and the dimensions of the other layers was also calculated using the height and width of the stairs as in table 1 [1]. The method of construction was strange. It consisted of layers of liben, in each layer 8-9 rows of liben. These layers were separated by layers of mats made of reeds furnished by a layer of gravel and sand $(8 \mathrm{~cm}$ thick). Rolls of rope (diameter $10 \mathrm{~cm})$ penetrates the building were also used to strengthen the construction [19] [1]. One of the main features of construction for this period is the magnitude of the walls (average thickness $3 \mathrm{~m}$ ). Temples were built in a different way from previous eras, where they are rectangular in shape and the entrance to one side, which represents the interface. The heart of the building can not be accessed directly from the entrance. There are vestibule sides at the entrance point.

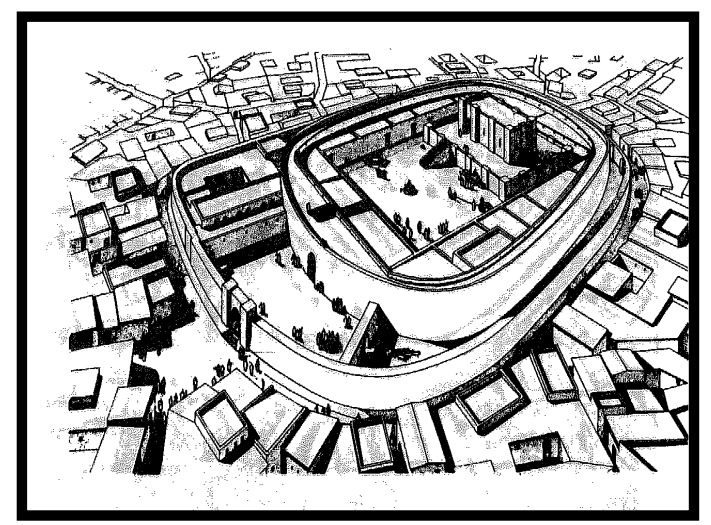

Fig. 3.7: Ashnona temple. [8]

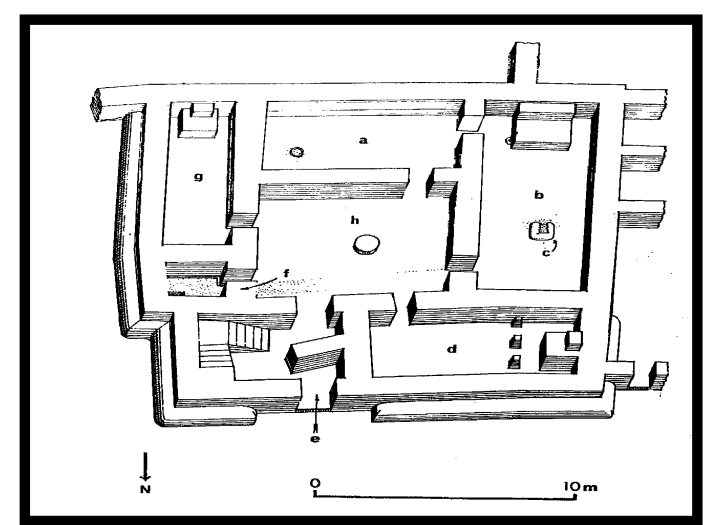

Fig. 3.8: Tel-Khafaji temple [8].

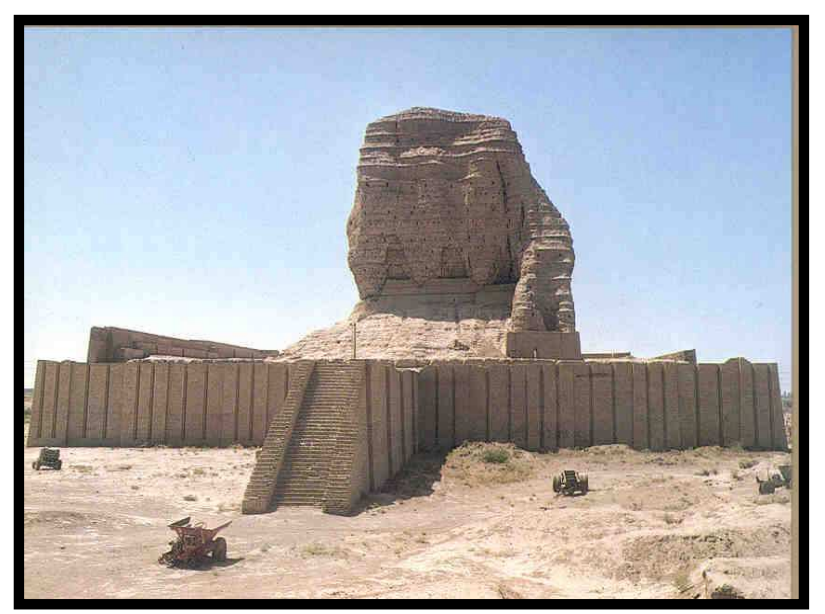

Table 1: Dimension of layers.

\begin{tabular}{|c|c|c|}
\hline layer & Height(m) & Area(m) \\
\hline 1 & 33 & $78 * 78$ \\
\hline 2 & 18 & $62 * 62$ \\
\hline 3 & 6 & $50 * 50$ \\
\hline 4 & 6 & $40 * 40$ \\
\hline 5 & 6 & $30 * 30$ \\
\hline 6 & 9 & $15 * 15$ \\
\hline
\end{tabular}

Fig. 3.9: Ziggurat of Dor- Kurigalzu (Aqarqouf)/18 
The four corners of the building had fortified wall and on the north-west in the inner part of the bench put a statue of worship. This scheme differs from previous one of moderation and internal court surrounded by rooms. The construction material was made of square liben $\left(45^{*} 45^{*} 10 \mathrm{~cm}\right)$, this liben was made of silt clay soil or sandy clay soil. The mortar material was used as an adhesive for liben or brick was made of mixed mud with water and some times straw is add in order to preserve the construction from natural symptoms for a longer period. Tar and asphalt were also used as plaster in foundations of the buildings and walls because they are available since ancient times in Hit. In addition, lime was used as plaster to build the foundations and walls because it is moisture proof and good cohesion [12].

\section{4- Historical Times: The Assyrians (4000 BC to 612 BC):}

The most important cities of Assyrian kingdom were Assyria (built on the projection of rock limestone), Kaleh and Nimrod. The kings of this kingdom were interested to build those cities and fortified them by walls and high defence towers as well as the construction of palaces, temples and ziggurats from stone material. The buildings were characterized by the carved the winged bulls and winged lions from stone, inscriptions and writings.

In the city of Kaleh, several palaces were built and entrances were decorated by huge statues. In the south western corner of the city, they built a palace called (Governor's Palace). It has a large courtyard located in the north, a large and long hall, offset-like hall in the south and ensures many rooms on the east and west sides.

The building material for foundations was liben except some foundations, based in the southern part, wage was used. The walls of southern halls were covered with a layer of asphalt from the base to a height of $65 \mathrm{~cm}$. The ground floors were coated with bricks.

The city of Dor-Churkin (Khorspad) is almost square in shape $(1760 * 1675 \mathrm{~m})$, having thick walls $(66.7 \mathrm{~m})$ which made it like a fort. The walls had 7 doors [8]. On both side of each door, there were eruptions winged. This is evidence on the evolution of greatness of architecture and construction at the time (Figures 4.1 and 4.2).

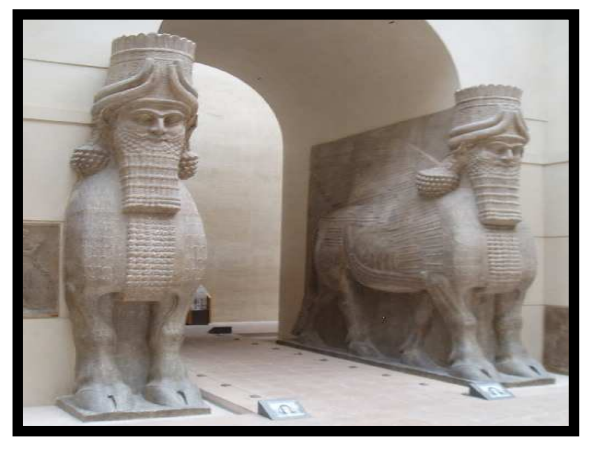

Fig. 4.1: The palace entrance [7].

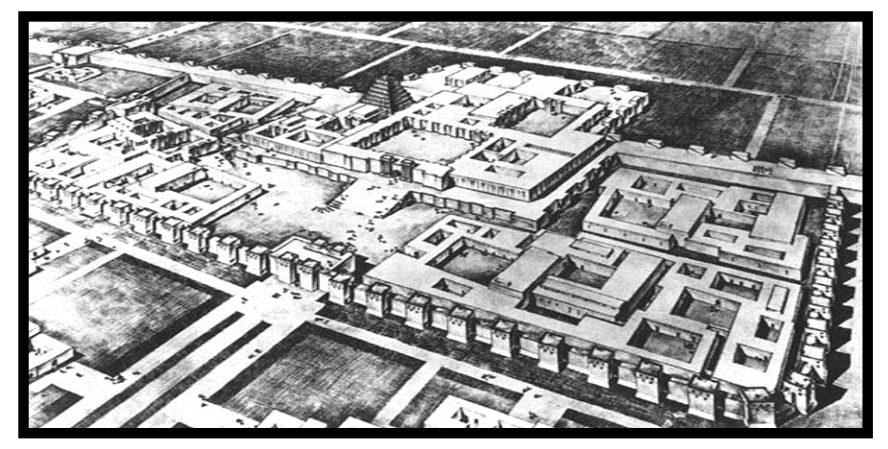

Fig. 4.2: Khorsabads palace, temple, and ziggurat [21].

Avery large palace inside the fence was also built on a terrace $12 \mathrm{~m}$ height from the ground level. They used stones (cubic in shape) as building material. The palace complex contains 200 rooms and 30 courts as well as a temple and ziggurat. The ziggurat base was square in shape $(42 * 42 \mathrm{~m})$. It consists of 7 terraces (layers) having individual height of $6.1 \mathrm{~m}$ which makes the total height $42.7 \mathrm{~m}$. Each terrace had a different colour. The areas of the terraces were decreasing from the ground to the top. Individual terrace might accommodate one building or more (Figure 4.2)[21]. In certain occasions, the terrace is composed of two rectangles with different dimensions one above the other (Figures 4.3 and 4.4). The terraces were painted by coloured chalk. The colours of the first 4 terraces were white, black, rose and blue respectively. The colour of the remainder terraces is not known because they perished. Spiral stairs were built to climb the ziggurat (Figure 4.4). 
Ninevah city was the capital for a long period of time for the Assyrian empire. Palaces, temples, barracks were built. The city was surrounded by a large fence. It was fortified by castles. The length of its outer wall is about $5 \mathrm{~km}$ and it has 15 gates. Nrkal gate was the biggest. Its height was $16.5 \mathrm{~m}$ and it was built on a terrace of liben ( $5 \mathrm{~m}$ above the surrounding plain) which makes the overall height $21.5 \mathrm{~m}$.Its entrance is $20.70 \mathrm{~m}$ long and $7.80 \mathrm{~m}$ wide, containing two towers on each side of the entrance. Stones were used to build the gate (Figures 4.5 and 4.6).

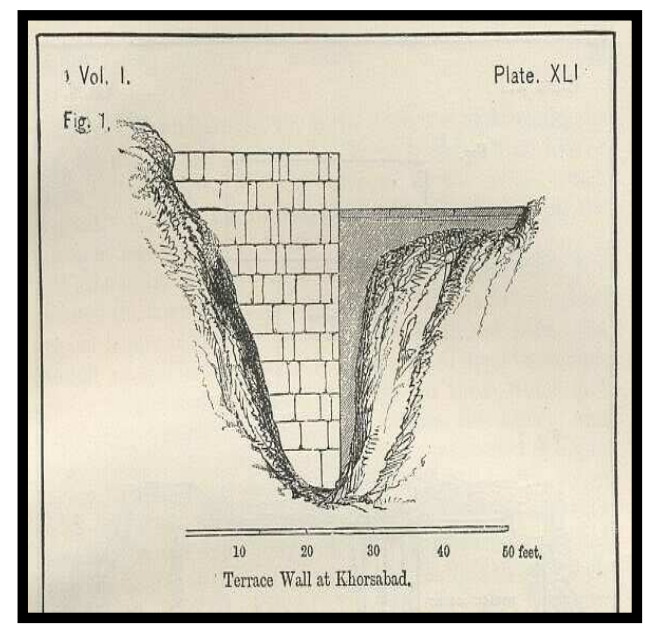

Fig. 4.3: Terrace of Khorsabad $[20]$.

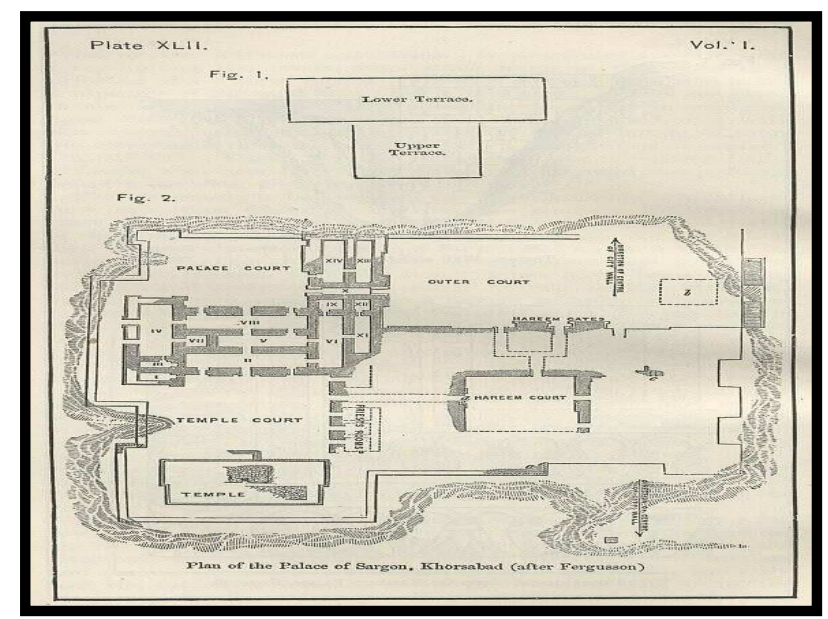

Fig. 4.4: Details of Khorsabad's Terrace and palace $[20]$.

The second big gate in the wall is called" Shamash". It rises about $10 \mathrm{~m}$ from tiling and the length of her forehead from the east entrance is $66 \mathrm{~m}$, and its entrance is $4.55 \mathrm{~m}$ I width. The outer gate interface was built from helan (local limestone) trimmed stone. In the interface 6 towers were built. The dimensions of these towers are $3.5 \mathrm{~m}$ in width about $22.50 \mathrm{~m}$ high. These towers are connected with the wall which is built with stones also. The walls are $10 \mathrm{~m}$ above the ground level. Other towers on the wall have the same dimensions apart from the two on the west side. They are $9.5 \mathrm{~m}$ wide with a portlet $6.75 \mathrm{~m}$ wide and the opening decreases in width till it reaches $4 \mathrm{~m}$.

Between western and eastern entrances a long the corridor $(61 \mathrm{~m})$ exists, paved by stones, some of the stones were engraved with the name of King Sennacherib [1].

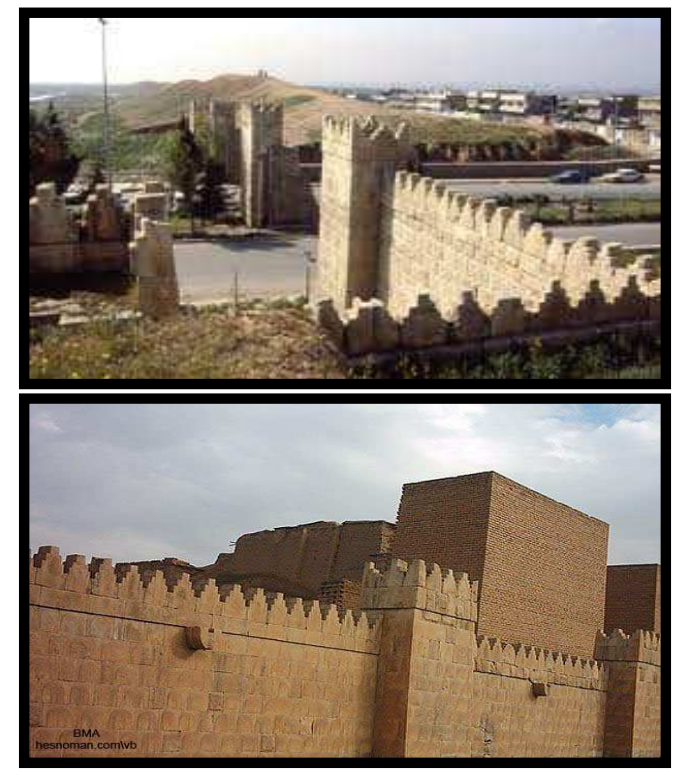

Fig. 4.5: Nrkal Gate and city Wall [22,23].

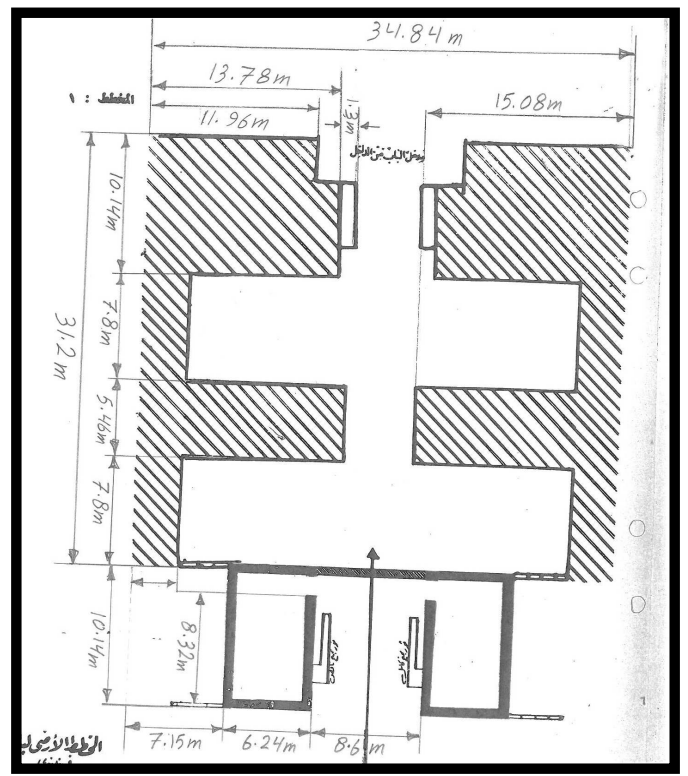

Fig. 4.6: Plan of Nrkal Gate [1]. 
The use the stone in the foundations and construction of the Assyrian building was very common because it was provided in the northern area from the mountains. They also used limestone and alabaster to coat huge walls. They used it for columns bases and thresholds for doors, as well as in paving the halls of the important buildings. They used solid rocks such as diorite, basalt and other to carve statues and panels and prominent images. Lime was used to join the small stones and was not used for big stones. Limestone was used to build columns that are $4 \mathrm{~m}$ high and at its top end spiral crown was put. The section of the columns was either square or circular and at the base there are animal statues. Some of the columns were polygonal with either 8 or 16 ribs.

Marvellous tunnel (Khariz) was dug 25m under the ground for collecting ground water in Arabella (Arbil). Ventilation opening were built at $42 \mathrm{~m}$ intervals. These ventilations were used for maintenance and cleaning of the channel [4].

\section{Last Babylonian Times (646 BC to $539 \mathrm{BC})$ :}

Babylon was the capital of the Babylonian kingdom. The city was surrounded by two walls, the outer one has a perimeter of $18-20 \mathrm{~km}$ and it consists of three parts. were built with liben and bricks. The internal wall consists of two walls: the first within the city having thickness of $6.52 \mathrm{~m}$ was built with liben and bricks, the second were smaller with thickness of $3.72 \mathrm{~m}$ built with liben. The internal wall contains 8 gates leading to the city, behind these two walls a moat of water exists (Figure 5.1). The distance between the two walls were $2 \mathrm{~km}$. Within this area the houses of ordinary people are built. Usually the houses were above the level of the street by building bench of liben. Wage and mortar tar were used for the walls. Crusader shape was the prevailing design for the houses. Above the foundation, liben was used. All the walls were plastered and painted bright white.

The city of Babylon characterized by its perpendicular streets ending at the gates of the city. Ishtar was the most famous gate. Its height is $14 \mathrm{~m}$ and it leads to Processions Street which was devoted to the celebration. The width of the street is $63 \mathrm{~m}$ and paved with sheets of stones, some of them are red stone and others are of limestone.

Number of big houses was built in Babylon. The most interesting one is that located south of the city on the procession street. It covers an area of $310 * 200 \mathrm{~m}$, with a grand entrance and consists of hundreds of rooms and other accessories such as yards. Five yards were built in that house, the largest one of is $60 * 50 \mathrm{~m}$ representing the Throne room (Figure 5.2). The summer palace which was referred to as "Babylon Mountain" due to its height was built in a square shaped having an area $250 * 250 \mathrm{~m}$. It was $18 \mathrm{~m}$ above the level of the street. It contains two main halls, the eastern and western, rooms and other accessories. All the walls of the palace built with bricks, plaster. Flooring consists of pouring by mixture of lime, sand and plaster with colour additives that gave a unique technology. Construction techniques and decorations reached its climax in the Babylonian era using glazed bricks to decorate the walls and floors and bench throne. Columns having crowns helical were also built (Figure 5.3).

The most important materials used in building palaces, temples and other buildings were large stone of basalt and diorite and other hard rocks. They were used in the foundations and in the work of hook and spin, which is based upon the big doors. 

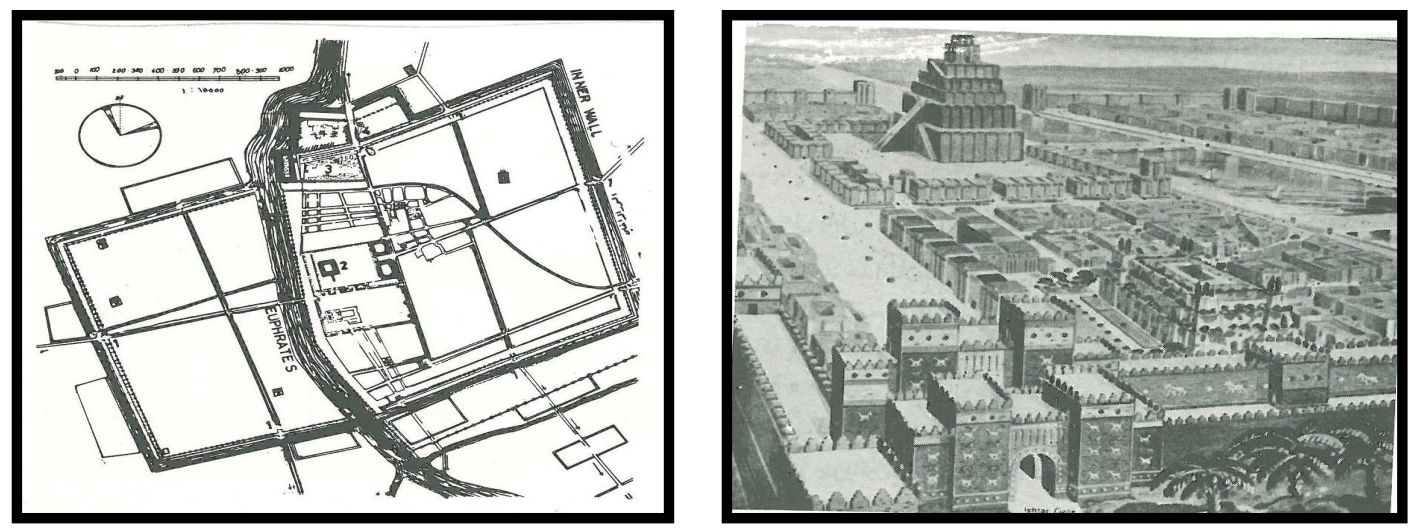

Fig. 5.1: Plan of Babylon City and its model [24].

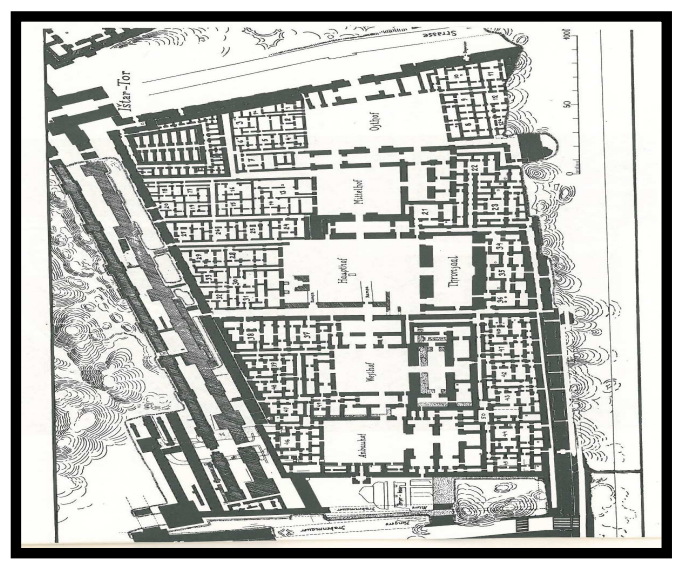

Fig. 5.2: South palace Plan [8].

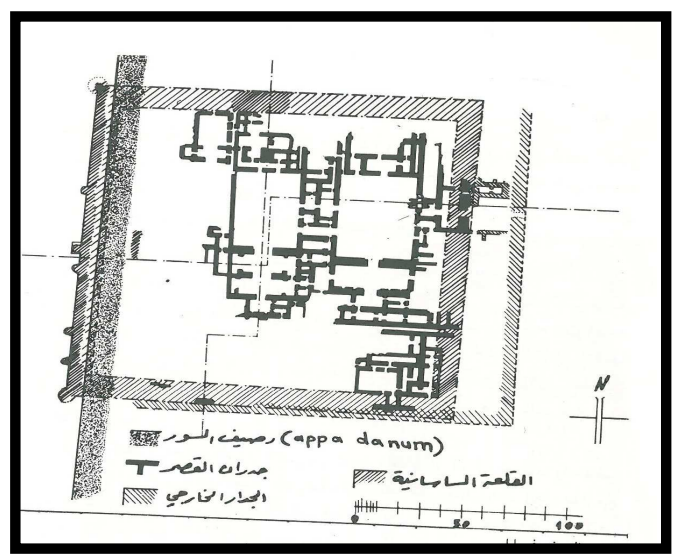

Fig. 5.3: Summer palace Plan [1].

Marble was used to cover the stairs. Hard stones were used in the construction of the pillars of the bridges on the Euphrates River. Liben $30 * 30 \mathrm{~cm}$ in size and wage made of grilled liben were used in the constructions. They grilled liben in special furnaces.

Glazing wage for inscription on the walls and doors were used having different colours. For the white colour they used tin oxide and for red, blue and yellow they used copper oxide, copper with a little lead, antimonies lead respectively. Mortar was used as an adhesive for bricklaying or liben which is mixture of soil with water to make mud. The asphalt and tar have been used to prevent the commune of moisture in building foundation and walls, also they used lime commune as a good cohesion to prevent moisture in the building, foundations and walls. Timber was used in the roofing of palaces and temples and also in making the doors [12].

The Babylonians used pillars instead of piers. Pillars built with bricks in semi-circular or triangle shape. Each pillar is composed of four interrelated pillars and some of them were rectangular, oval and both are built of bricks. They have the same diameter at the top and bottom, the diameter at the bottom was gradually descending to the top.

The Babylonians used bricks to built domes. In Sharubak a room was found having a round-roofed bricks. The bricks were laid horizontaly one on top of the other. The number of bricks was decreasing in a descending order to the top. This technique is still in use now and is called the capollay [10].

The most important monument in the city is the Hanging Gardens of Babylon, which was built in the northeast corner of the southern palace (Figur4.4)[24]. The building is almost rectangular (size $42 * 30 \mathrm{~m})$. Its floor is lower than that of the palace and it contains14 similar rooms $(2.20 * 3 \mathrm{~m})$. These rooms were distributed on both sides of narrow corridor.A well with three openings beside each other was found in one of middle rooms. Roofs of these rooms were arched and a thick layer of soil was laid on the roofs for agricultural purposes (Figure 5.4). 


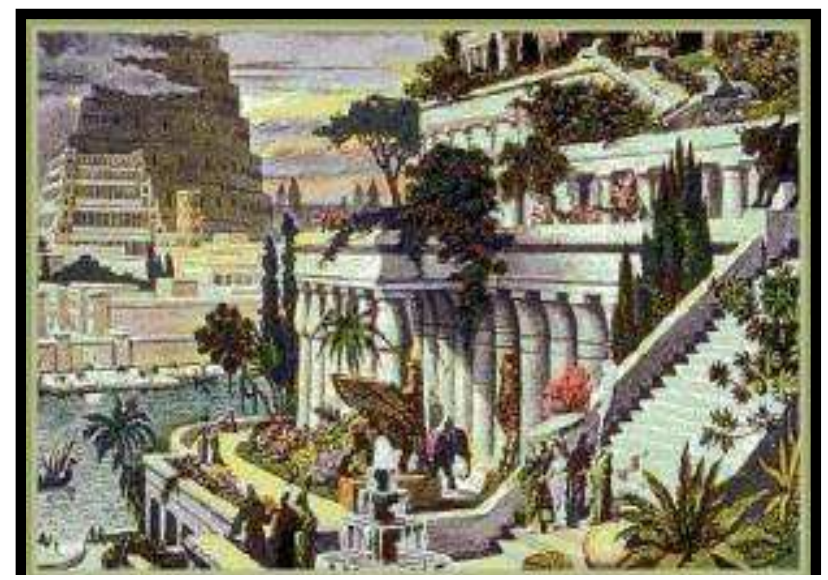

Fig. 5.4: Imaginary site for Hanging Garden [10].

Five large temples were found in Babylon, the largest is the temple of god Murdoch (Temple Aasangkela). It contains the famous Tower of Babel, which has a square base $\left(91.55^{*} 91.55 \mathrm{~m}\right)$. The sides of the tower are parallel to the geographic directions. The inner portion was built using liben while the outer part was built with bricks (15m thick). The foundation is built on a layer of pure mud, which is with impermeable.

Hooks of wood were found linked to the base from the inside through the cavities and the other end tied to the mud layer. They intended to tighten the base strongly to the foundations.

The tower consists of seven layers getting smaller in size in the upward direction. Climbing the tower can by achieved through three staircases. The middle stair case is $62 \mathrm{~m}$ long and $9 \mathrm{~m}$ wide. The lateral staircases are connected to the middle at the second and third layers respectively. The temple is composed of a group of buildings and rooms surrounding the courtyard (Figure 5.5). The dimensions of the seven layers of the tower are tabulated in table 2 [1].

Table 2: Dimensions of the seven layers of Babel tower [1].

\begin{tabular}{|c|c|c|c|}
\hline layer & Longed(m) & Width(m) & Height(m) \\
\hline 1 & 91.55 & 91.55 & 33.52 \\
\hline 2 & 79.45 & 79.45 & 18.31 \\
\hline 3 & 61.14 & 61.14 & 6.13 \\
\hline 4 & 51.99 & 51.99 & 6.13 \\
\hline 5 & 42.38 & 42.38 & 6.13 \\
\hline 6 & 33.67 & 33.67 & 6.13 \\
\hline 7 & 24.52 & 24.52 & 15.21 \\
\hline
\end{tabular}
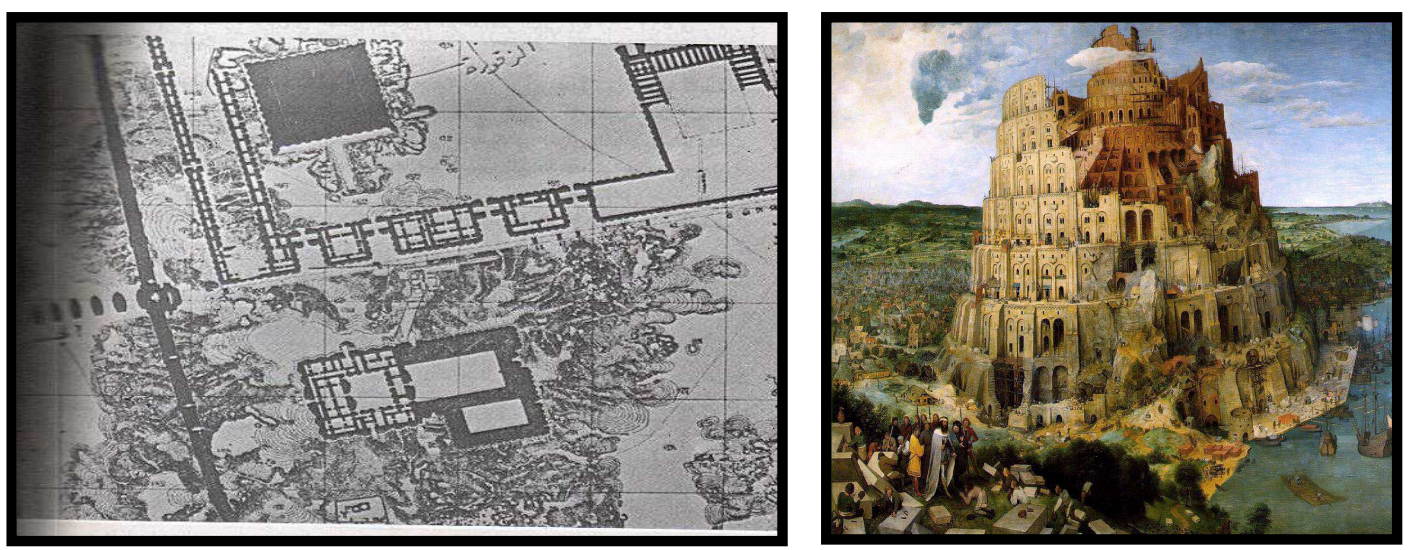

Fig. 5..5: Plan view of Ziggurat and Temple Aasangkela and imaginary photo of Babel Tower[1]. 
The Ishtar temple went into three periods of construction. It is rectangular in shape $(37.12 * 31.05 \mathrm{~m})$ having 20 facilities and the courtyard. Its plan is identical to other temple plan prevailing in old Iraq. A huge wall built with mud and sanctified clay surrounds the temple. There is a square courtyard in the middle. On the west side of the silo there are three entrances. The middle entrance is important because it is similar to the main entrance of the temple. Surrounding the temple is a pavement build with bricks and tar to protect the external walls. At both sides of the wall a set of sorties were built to support the wall (Figure 5.6).
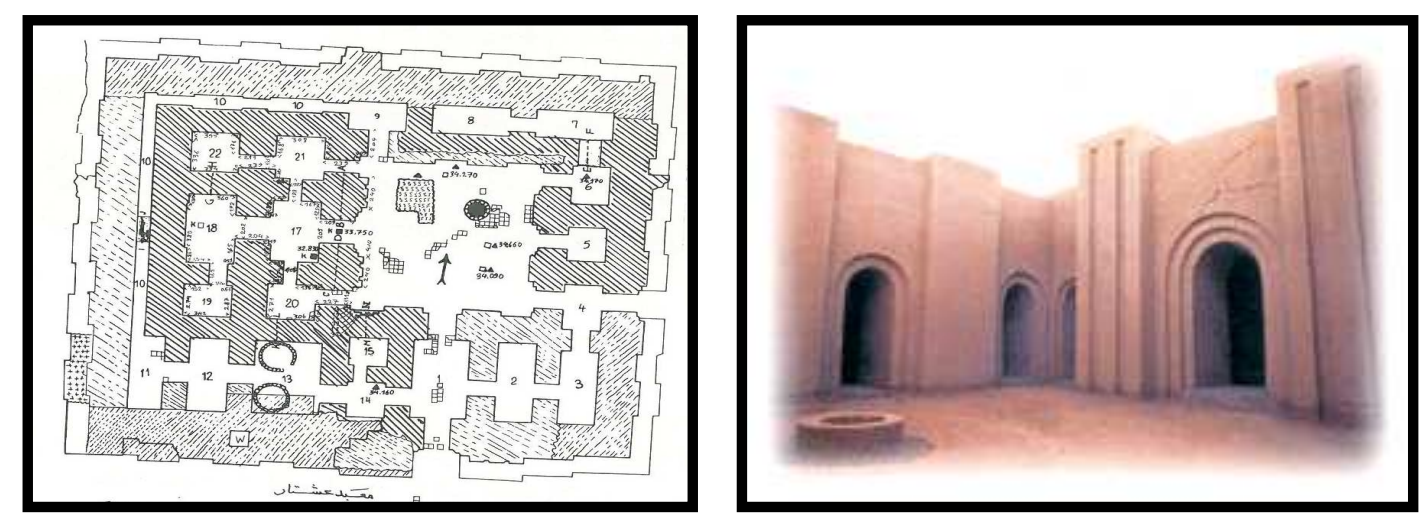

Fig. 5.6: Plan of Ishtar Temple and photo of inside temple $[1,25]$

In summary, there are three patterns of building construction for ziggurat or towers. They are: Rectangular tower or ziggurat which can be climbed through ladders by three stairs, one in the middle and the others two from sides. This type had spread in the southern part of Mesopotamia (e.g. Tower of Ur, and Uruk Tower). The second type which has been spread in the northern part of Iraq, is the square ziggurat or tower. This type can be climbed through gentle ramps built on its front (e.g. towers of Assyria, Kaleh, and Dor-Sharukeen) (Figure 5.7). The third type is that having square base and climbing is done to the lower floors by stairs and to other floors by ramps as in the tower of Babel.

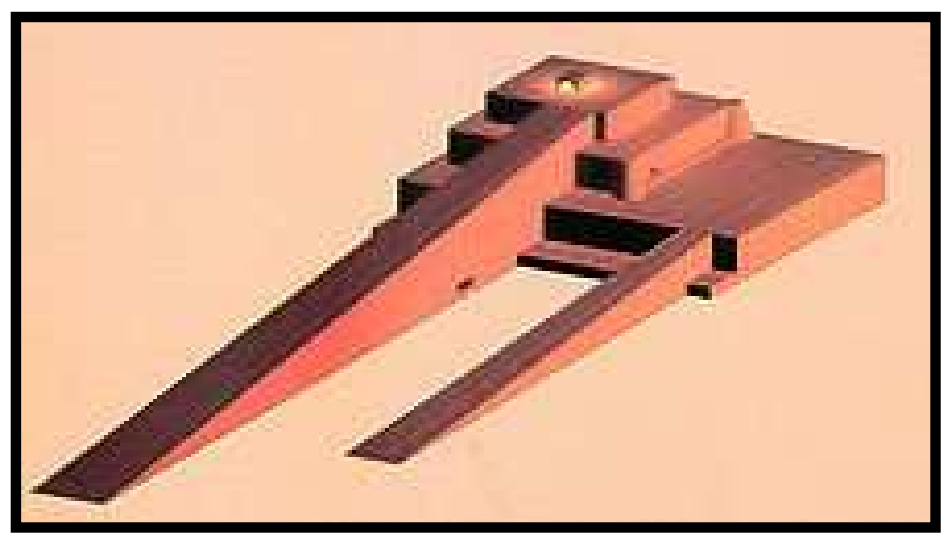

Fig. 5.7: Second model of ziggurat [26]. 


\section{Foreign Rule of Mesopotamia (539 BC to 637 AD):}

6.1- The Persians (Alakmignon) (539 BC to 331 BC): After the fall of the Kingdom of Babylon by the Persians, they re-reconstructed the Babylonian cities and palaces were built. The remains of their buildings are so little.

5.2- Romans (331 BC to 323 BC): Alexander the great defeated the Persian state and made Babylon his capital. The most important construction was building the Romanian playground, which consists of bleacher playground semicircular and in front of it courtyard divided into two parts by semicircular columns jointed by polygonal pillar (Figure 6.1).

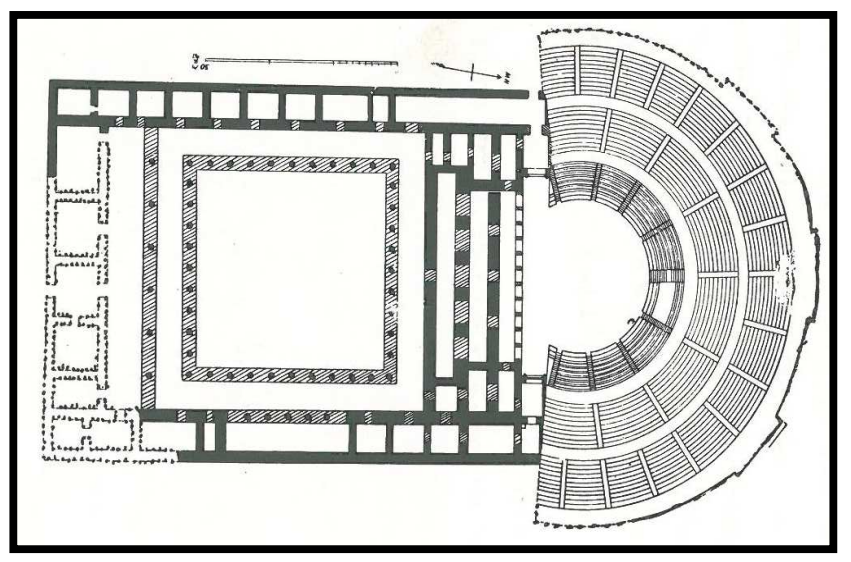

Fig. 6.1: The Romanian Playground [1].

6.3- The Persians (Alfrthein) (126 BC to 227 AD): Alfrtheon had built their capital in Tifuson (Al-Madaien), also they reconstructed the Iraqi cities (Babylon, Kish, Navarre, Warka and Assyria), and built temples on the Romanian style. Their buildings were characterized by huge walls built with liben in large sizes.

In Ashur city, the buildings were unique by its columns. Geometric shaped stones were used instead of liben. They started to build open Iwan with squares courtyard surrounded by colonnaded (peristyle) (Figure 6.2).

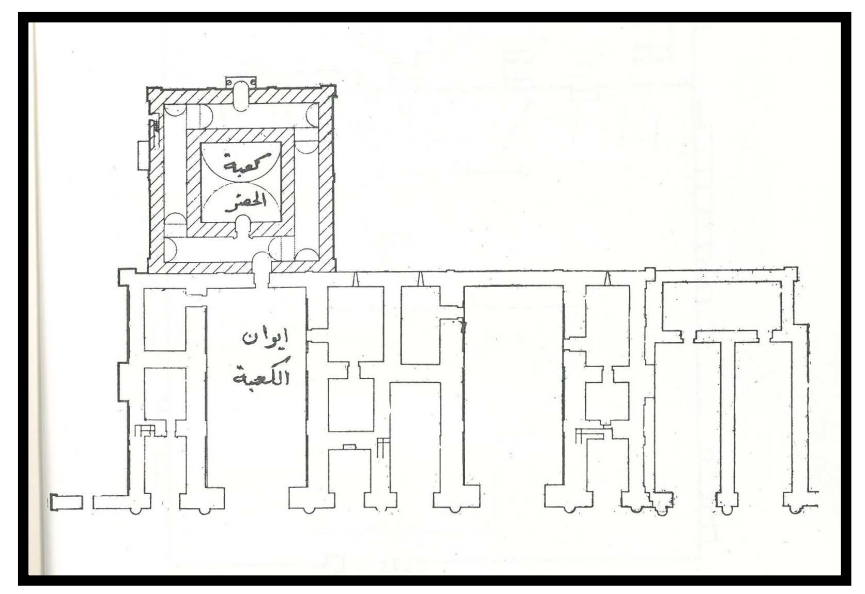

Fig. 6.2: Plan of Persian open Iwan [1].

Many cities were built between Iraq and Levant as trading caravan's centres. The inhabitants of the Assyria city reconstructed their city, and built houses and two types for rich and ordinary people. They used bricks and plaster and the high level class houses were characterized by its precision and accuracy of the horizontal distances. The Iwan became the most important place in the house or palace. The floor was tilled with pieces of geometric tile. The building adopted provided suitable 
places to live according to the seasons, sun falls, and the air and termination times of the day. In addition to use the geometric stones in foundations, the development of vertical walls that are covered at the top by a layer of mortar and plaster, the crakes were filled with same mortar. The second type of houses for the ordinary people, stones of irregular shapes were used (yellow brittle limestone - hallan). The stones were fixed with liben, in the same way the Assyrians used to build the deep foundations over liben. The liben was pure, yellow coloured and contains small size of unknown source material. Most of these houses have Iwan which is opened from north. Mortar plaster was used for constructing the sanitary system. There were foundations for the walls (Figure $6.3)$.

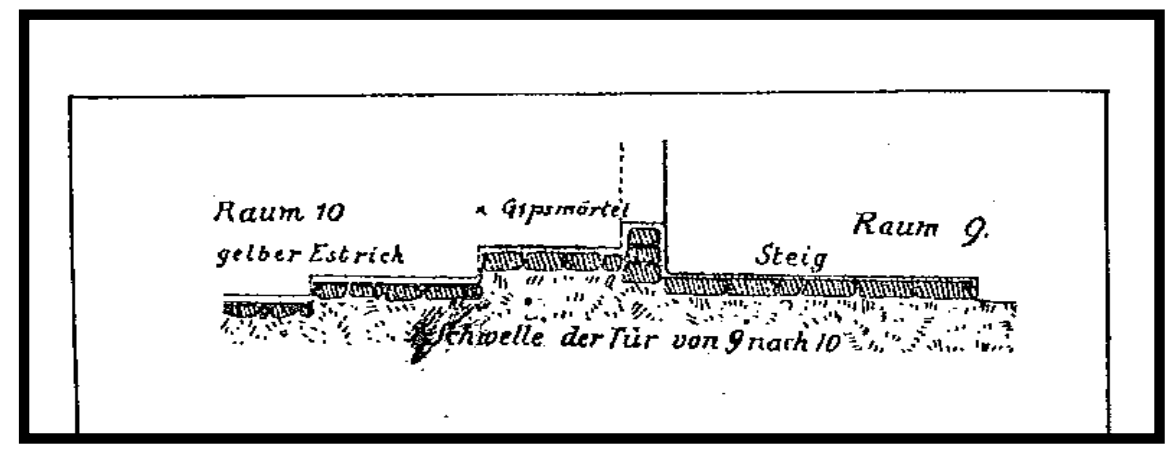

Fig. 6.3: Cross section showing the foundation (scale 1:40) [27].

6.4- The Sasanian ( 224 AD to 637 AD): Tesfon was the capital of Mesopotamia in this era. A famous palace known as Ewan Chosroes (tesfon arch) (Figures 5.4)[29], was constructed with plaster and bricks. The area of the palace is $300 \mathrm{~m}^{2}$. The width of the entrance of the ewan was $25.63 \mathrm{~m}$ and it was $43.72 \mathrm{~m}$ long and the thickness of the bottom walls about $3 \mathrm{~m}$.[1]

. The walls from the interior side were covered with layer of plaster containing decorations and many pictures (Figures 6.4 and 6.5).

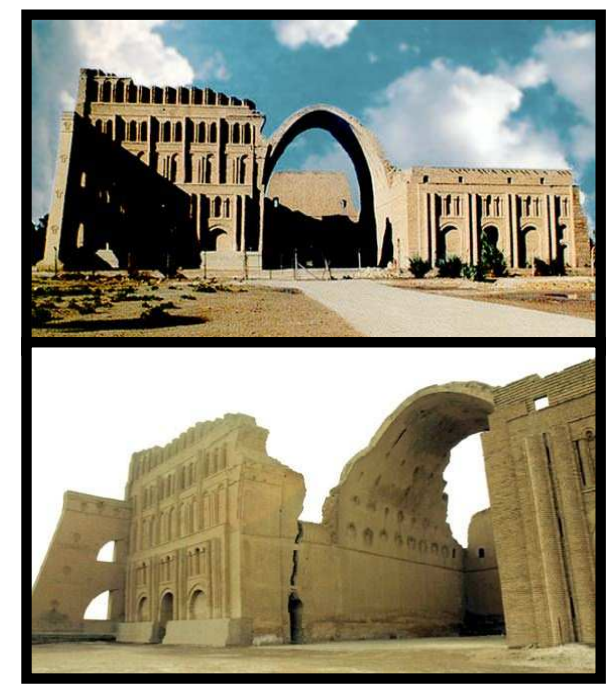

Fig. 6.4: The Photo of Ewan Chosroes [29].

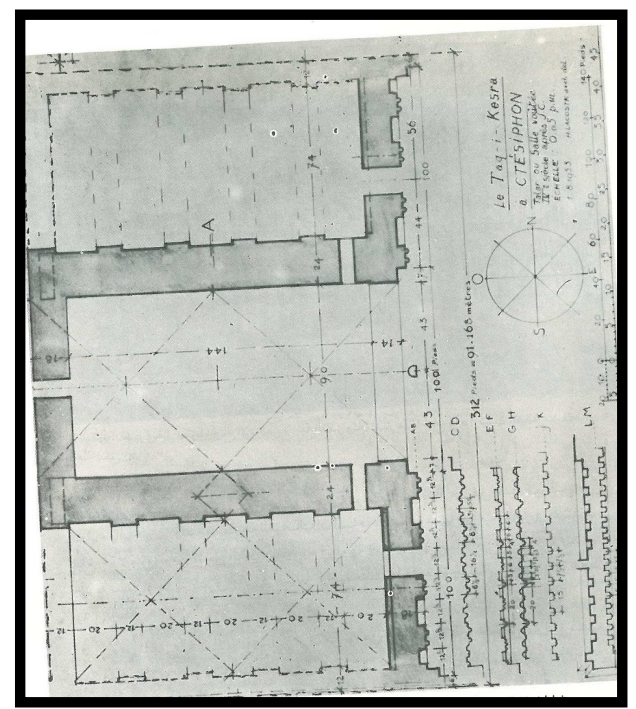

Fig. 6.5: Plan of Ewan Chosroes

[1].

6.5- The Hatra City ( 250 BC to 226 AD): This city grew up in the desert between the Romans and Persians empires. It is located southwest of Mosul city, because it became a military center for Frthein, many Arabs lived in the city seeking protection for their temples. For this reason the city contains many temples in addition to the towers, walls and palaces. 
A wall $8 \mathrm{~km}$ long built by mud surrounds the city from outside with and surrounded by a deep trench outside. The internal wall is $6 \mathrm{~km}$ long and composed of two walls with $12 \mathrm{~m}$ distance between them. The material used for building stones. The city has 163 towers, with 4 doors parallel to the geographic directions. [28]

The Hatra temple is one of the important buildings in the city because of its characteristic architectural art and construction technology used (Figure 6.6). It has a rectangular shape (length of $437.5 \mathrm{~m}$, width $322.5 \mathrm{~m}$ ). Another wall exists extending from the northern wall to the southern wall to separate the court from the buildings. It contains several buildings, some of which were built similar to the Greek style with geometric shaped stones [1].

Another famous temple is called Marm. It has a rectangular shape $(22 * 17 \mathrm{~m})$. The rooms are also rectangular $\left(14^{*} 11 \mathrm{~m}\right)$. They were built on a platform, surrounded by rows of columns in a circular form, down of them exists a second row of columns. To approach the temple room, one must limb 7 stairs having a height of $1.6 \mathrm{~m}$. This type of construction is called Dipteral[28] (Figure 6.7).

Most prominent features of Hatra buildings is the use of geometric stones with plaster as mortar material, also they used hooks to connect the stones. The gaps between stones were filled with a mixture of cement plaster and small stone.

New method was used in roofing, where stones used in the geometrically trimmed in roofs shaped as semi-cylindrical. Some of the arches and vaults extend for more than a half circle. They were built in radiation style (Figure 6.8).

The construction in Hatra area is characterized by strong, beauty and art, and show advanced civilian emulate the great civilizations.

In ancient Mesopotamia, the use of stone was very common in northern Iraq because of it is availability. In addition, liben as a sacred substance was also used in the construction of temples. The central and southern regions, which are characterized by silty soil, the use of liben, bricks and grilled liben was the prevailing materials in construction because of the lack of stone. Bricks and clay used in advanced techniques reflecting sophisticated engineering. At certain occasions, stones were used in the construction in southern Iraq when it is available (e.g. Uruk). In the marshes, the reed and papyrus are used for building houses (Figure 6.9). Cane was used some times in some buildings as pillar in the ziggurats.

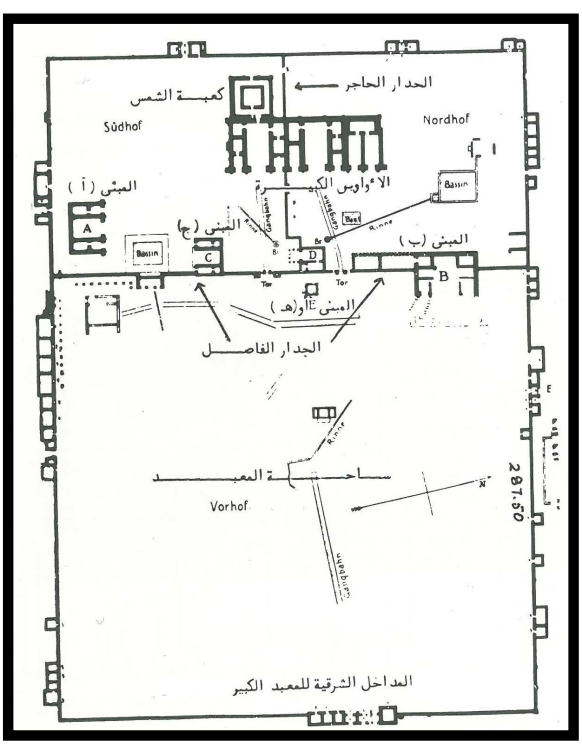

Fig. 6.6: Plan of Hatra Temple

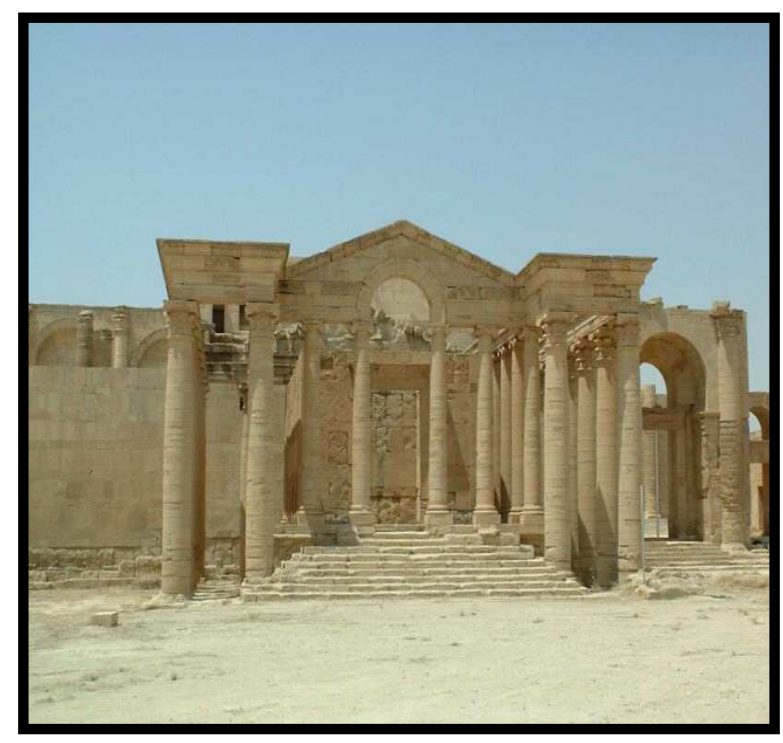

Fig. 6.7: Marm temple [30]. 

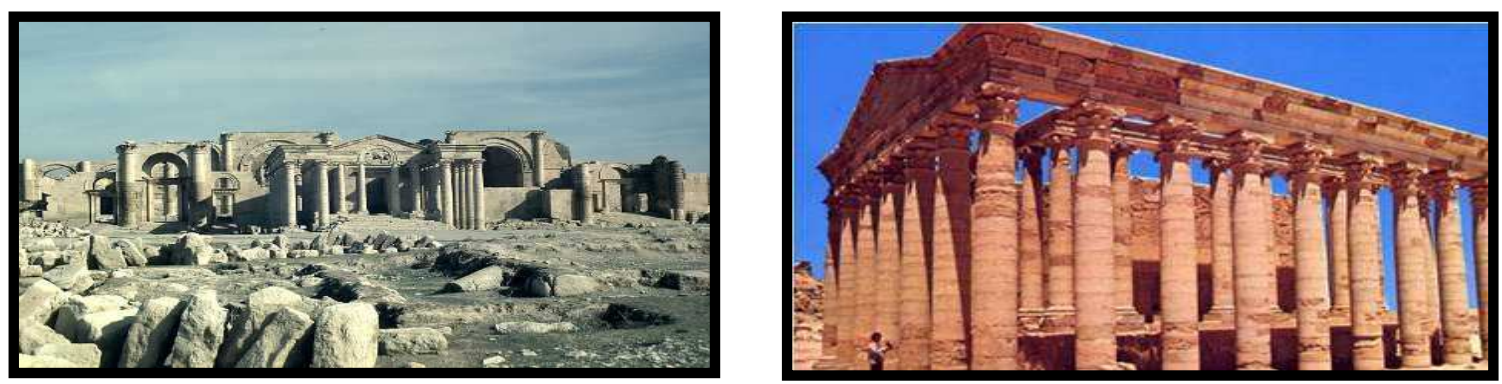

Fig. 6.8: Building Style in Hatra [31].

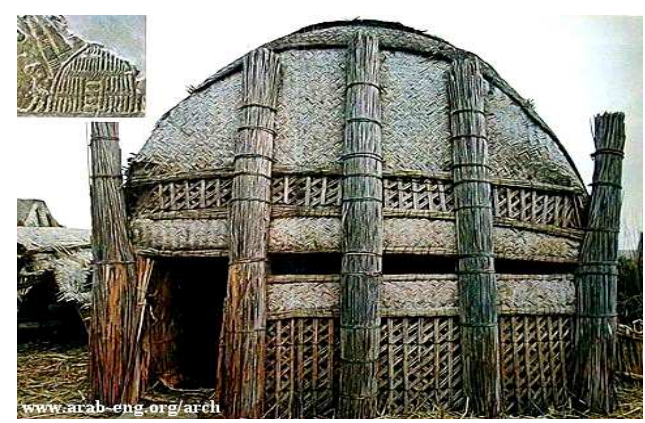

Fig. 6.9: The marshes house built from reed and papyrus [33].

\section{Summary:}

During the Old Stone Age (150000 to 12000 BC) people in the old Mesopotamia lived in caves. They were hunters. Later in $(12000-8000 \mathrm{BC})$ people started to cultivate the land and gradually transformed to farmers. The advances in the life style forced them to leave their caves and live near their land in simple designed houses. Gradually with time progress these isolated houses became villages and later cities. They used the available material in their buildings. All the buildings were made of mud and or limestone, which are the most abundant material in Mesopotamia.

Religious believes had its influence on the construction of buildings. In the late stages of the Stone Age, the inhabitants of Mesopotamia started to build temples. These temples started as simple buildings and then it was growing in size and height with time. This is due to the fact that the higher the temple is the closer the person will be to his God.

Foundations for buildings did not exist till late Stone Age. The foundations started as simple stones put in a row and then they used rafts for their temples as it was growing in size.

The materials used were simple and the stones were irregular in shape at the start. Then it is well recognized that with time, the stones used were of regular geometric shape. The dimensions of the stones were relatively small at $8000 \mathrm{BC}$ and they started to use bigger stones with time progress.

No decorations were noticed in earlier buildings and later colored and sculptures were used as well. The strength of the buildings and distribution of the forces were not that sophisticates as a start. With time progress, the ancient engineers used various methods to strengthen the foundations as well as the walls.

It is noteworthy to note that the geology of the area played an important role in the selection of building materials. In the north of Mesopotamia, the available material is limestone while is the central and southern parts it was mud. In view of this fact, limestone was the most abundant material used in constructions in the north while mud was the predominating material in central and southern parts of Iraq.

When we look at the materials they used and the thicknesses of walls, it is evident that they were perfect for the weather conditions in Mesopotamia where they were conserving the heat in winter and keeping the buildings cold in summer. 


\section{Conclusions:}

The birth of the idea to establish the first permanent home dated back to more than $6000 \mathrm{BC}$. Humans used engineering innovative that led him to use the advanced construction material available in the environment and make it suitable for construction. Solutions were found and technical obstacles were solved, and the result was building the most beautiful and most luxurious palaces and temple and ziggurats. It is astonishing to see these achievements were done using natural materials and very simple tools.

Ancient people in Iraq were looking forward to get closer to the source of the sky God and to achieve this goal, they built towers and ziggurats. These carried the art of construction projects for the ultimate graphics and this is indicates that the construction in Iraq had relied on maps and engineering calculations on the distribution of loads and taking into consideration the direction of wind and weather effects. All these achievements also imply that they had good knowledge about the principles of geology, chemistry and other sciences which allowed them to execute these huge projects.

Terraces were used as the base ground for constructing the big temples and ziggurats. It was designed to take the heavy load of the building.

The materials they used like brick for being a good insulating material, keeping the heat in winter and summer, retains moisture and is used as engineering material(mortar) also has a long life in construction.

Now a day in Iraq, the prevailing building materials are cement and iron. These materials raise the heat of the building during summer and cool them during winter. On the contrary to these materials, the materials used by ancient inhabitants of Iraq were good thermal isolators.

Engineers and contractors in Iraq should learn from the ancient engineering practices in Iraq. Adopting some of these techniques and the construction materials which were used will definitely improve the quality of buildings.

\section{References:}

[1] S.Yuosaf, History of Iraqi Architecture in Various Eras, edtied by Alrashed house for publishing, 1982.

[2] Dr.H.A. Kamona., Employment of Local Environmental Resources in the Built Unit of the Urban Fabric within the Framework of Preserving the Architectural Heritage, The Planer and The Development Magazine, Baghdad University, vol.22 (2010)1-20.

[3] www.Babylontimes.net.

[4] Dr. A. Sousa, History of Mesopotamian Civilization, In The Light of Irrigation Agricultural Projects, Al Huriya Printing House, Baghdad, vol.1, 1981.

[5] www.En.wikiwdia.org.

[6] Dr. A. H. Zayed, Middle Immortal, Introduction in the History of Civilization of The Near East from Ancient Times Till 323 BC.M., Al Nahda Al Arabian House, 1967.

[7] www.donsmaps.com.

[8] L. Seton, The Archaeology of Mesopotamia from The Old Stone Age Till The Persian Conquest, translated Tilb M., Revised Edition, Al Sham press, Damascus, 1993.

[9] F. Safar, M. A. Mustafa, L. Seton, Eridu, state organization of Antiquates and heritage, 1981.

[10]L. D. Port, The Mesopotamia, Assyrians and Babylonians Civilization, translated by Kamal M., second edition, the state Egypt republic for books, 1997.

[11] Dr. T. Sileman, Studies in the Ancient Civilization of Western Asia from Ancient Times to 1190 BC.M, Damascus House, first edition, 1985.

[12] Dr. M. L. Mohammad, The Iraqi Ancient History, Till the End of third thousand BC., 1977.

[13] www.m3mare.com.

[14] F. Bassmachi, Treasures of The Iraqi Museum, The Harrua House for Printing and Publishing, Baghdad, 1972.

[15] www.aregy.com

[16]www.iraqfineart.com 
[17] www.ar.wikipedia.org.

[18] www.iraker.dk

[19] www.shmskrabla.com.

[20] M. A. George Rawlinson, The Seven Great Monarchies Assyria, of the Ancient Eastern World, vol.1.

[21]www.mesopot.com

[22] www.dm3twlh.com

[23]www.hesnoman.com

[24]www.vb3.nghmat.com

[25]www.iraqiforum.com

[26]www.elaphbolg.com

[27] V.Andrei , H.Lentsin ,Hellenistic City of Assyria, translated by A Hassan A. R. K., Press book Printing and Publishing House, Mousal University, 1987.

[28] A. R. Al Husanai, Iraq's Ancient and Recently, third edition, Al Erfan Press, Saida, 1958.

[29]www.quran-m.com

[30] www.dam-flower.com

[31]www.top22arab.com

[32] J. C. Margon, The Ancient Population of Mesopotamia, The Northern Syria, translated by Salim S. Al Essa, Alaa Al Dean publishing House, Damascus , 1999.

[33]www.arab-eng.org

[34] www.Mesopotamia.com $\backslash$ facbook. 
Trends in Civil Engineering

10.4028/www.scientific.net/AMR.446-449

Progress of Building Materials and Foundation Engineering in Ancient Iraq 10.4028/www.scientific.net/AMR.446-449.220 